\title{
1 Ecosystem gross primary productivity after autumn snowfall and melt events in a mountain
}

\section{2 meadow}

3 P. C. Stoy ${ }^{1,2, *}$, A. M. Khan ${ }^{2}$, K. Van Dorsten ${ }^{1}$, P. Sauer ${ }^{1}$, T. Weaver ${ }^{3}$, E. N. J. Brookshire ${ }^{4}$

$4 \quad{ }^{1}$ Department of Biological Systems Engineering, University of Wisconsin - Madison

$5 \quad{ }^{2}$ Nelson Institute for Environmental Studies, University of Wisconsin - Madison

$6 \quad{ }^{3}$ Department of Ecology, Montana State University

$7 \quad{ }^{4}$ Department of Land Resources and Environmental Sciences, Montana State University

$8{ }^{*}$ Corresponding author: pcstoy@wisc.edu 


\section{Abstract}

11 Vegetation productivity is increasing across much of the U.S. Northern Great Plains but is

12 decreasing in some nearby Northern Rocky Mountain grasslands due to increases in aridity.

13 Mountain grasslands support critical ecosystem services that are under threat from ongoing land

14 use and climate changes, and it is important to understand their function across all changing

15 seasons. Observing the full range of montane ecosystem productivity is challenging because site

16 access is often difficult during the "shoulder seasons" in spring and autumn if the snowpack is not

17 fully developed or degrading. It is unclear if decreases to montane grassland productivity from

18 drying autumns can be offset in part by late-season green-ups after precipitation events. These

19 include the snowfall/snowmelt periods that often characterize the summer-to-winter transition in

20 the Northern Rockies. Here, we quantify the ecosystem carbon uptake that occurs after snowfall

21 and melt in climatological autumn (September, October, and November) in a montane grassland

22 in Montana, USA using a combination of eddy covariance, phenological camera, and remote

23 sensing analyses. Carbon dioxide flux follows a diurnal pattern after autumn snowmelt events

24 despite overall ecosystem losses of $\mathrm{C}$, suggesting that post-snowmelt photosynthesis helps dampen

25 C loss during autumn and provides fresh photosynthate to support ecosystem functioning. Light-

26 saturated photosynthesis after two snow events was not different than before snowfall $(\sim 6 \mu$ mol

$27 \mathrm{CO}_{2} \mathrm{~m}^{-2} \mathrm{~s}^{-1}$ in 2016 and $\sim 2.5 \mu \mathrm{mol} \mathrm{CO}_{2} \mathrm{~m}^{-2} \mathrm{~s}^{-1}$ in 2017); observations are consistent with the notion

28 that canopy photosynthesis is resistant, rather than resilient, to the first snow disturbances. MODIS

29 observations also suggest that post-snowfall increases in NDVI can occur but do not happen every

30 year, such that late-season photosynthesis is not a reliable source of fresh photosynthate. These

31 late-season carbon uptake events likely play a small role in the annual ecosystem carbon balance

32 but may be disproportionately important for organisms faced with dwindling late-season forage 
33 and regrowth in spring. Future efforts should seek to understand the community and ecosystem

34 consequences of vegetation functioning during autumn as part of an expanded effort to understand

35 phenological changes during this under-studied and changing time of year.

\section{Keywords}

38 Eddy covariance; gross primary productivity; montane grassland; normalized difference

39 vegetation index; phenology; snow

\section{Introduction}

42 North American grassland productivity is predicted to increase due to vegetation responses to

43 future climatic variability (Hufkens et al. 2016) despite well-documented increases in aridity

44 (Novick et al. 2016). Widespread greening has already been observed across the Northern Great

45 Plains (Brookshire et al. 2020), but the growing season across many surrounding montane regions

46 has become shorter due to hydrologic stress (Wood et al. 2021), with implications for

47 biogeochemical cycling and ecosystem functioning. Late-season productivity, for example, has

48 declined by over $50 \%$ since the late 1960 s at a well-studied montane grassland site in the US

49 Northern Rocky Mountains due to increases in aridity (Brookshire and Weaver 2015), despite

50 regional climate changes that are often favorable for plant growth (Bromley et al. 2020). These

51 observations suggest that Northern Rocky Mountain grasslands are responding differently than

52 Northern Great Plains grasslands to recent climate changes and may continue to do so.

53 Montane grasslands support diverse biological communities (Körner and Spehn 2019) and

54 provide critical ecosystem services (Körner 2004) that are under threat from changes to land use

55 and climate (Egan and Price 2017) including snow dynamics (Harpold et al. 2012). Carbon 
sequestration is a critical ecosystem service that may be substantial in montane grasslands (Reed et al. 2021) but is highly variable across space and time - due in part to climate and management - which may result in net annual $\mathrm{CO}_{2}$ losses (Rogiers et al. 2008). Regardless of net annual carbon efflux, the documented pronounced late season declines of vegetation productivity in montane

61 grasslands of the northern Rocky Mountains is cause for concern for the organisms that rely on

62 fresh vegetation for overwintering success (Hurley et al. 2014, 2017; Loe et al. 2020).

Despite large declines in biomass during the late growing season before snowfall in a

64 mountain meadow in Montana (Brookshire and Weaver 2015), research at the site and

65 communication with land managers has led to the speculation that precipitation pulses - often from

66 snowfall and subsequent ablation (hereafter "melt") - support a "recovery" of production during

67 the transition from the dry summer season to winter. This notion is consistent with a hypothesis

68 that montane grassland photosynthesis is resilient to late-season snow events and can quickly re-

69 establish previous function after melt, much in the same way that grass photosynthesis tends to re-

70 establish quickly following harvesting (Novick et al. 2004; Stoy et al. 2008), grazing (Parsons et

71 al. 1983), and heat waves (Hooveret al. 2014). Alternately, canopy photosynthesis in mountain

72 meadows could simply be resistant to snow disturbances following a growing body of cold-season

73 research that demonstrates that photosynthesis can occur under snow (Starr and Oberbauer 2003;

74 Street et al. 2012; Lundell et al. 2008) and the notion that grass productivity is resistant to minor

75 disturbances, including for example mild drought (Batbaatar et al. 2021). In this scenario,

76 ecosystem carbon uptake would not meaningfully differ before and after snow events and

77 ecosystem carbon uptake would have little response to snow apart from the limitations to

78 photosynthesis caused by cold conditions and diminished light availability under the snowpack. 
79 Most research to date has characterized the rapid re-establishment of photosynthesis after

80 snowmelt in spring (Julitta et al. 2014; Vitasse et al. 2017; Wohlfahrt et al. 2008), with fewer

81 studies of ecosystem carbon uptake in response to short-duration snow events during the autumn-

82 to-winter transition.

83 Ecological research in montane ecosystems during autumn and the transition from the

84 vegetative growing season to winter is lacking, in part due to the difficult travel conditions created

85 by snowfall and the subsequent melt periods that make roads impassable and over-snow transport

86 onerous. This has hindered our understanding of ecosystem functioning during this critical and

87 changing period (Piao et al. 2008), especially as compared to its spring counterpart (Gallinat et al.

88 2015). To help remedy this situation for the case of montane grasslands, we studied the effects of

89 autumn snowfall and melt periods on ecosystem carbon uptake and loss in a montane grassland in

90 Montana, USA that has been studied for decades. Specifically, we characterize the surface-

91 atmosphere exchange of carbon dioxide and energy, greenness, and the normalized difference

92 vegetation index (NDVI) before, during, and after winter snow accumulation and melt events in

93 September, October, and November - climatological autumn - using eddy covariance, phenocam,

94 and remote sensing measurements and ask if observations follow a pattern of ecological resilience

95 or resistance to autumnal snow.

96

\section{Methods}

\section{$98 \quad$ Site information}

99 Observations were made at the Bangtail Study Area (Brookshire and Weaver 2015; Weaver and

100 Collins 1977), which hosts the Bangtail Mountain Meadow eddy covariance research site (US-

$101 \mathrm{BMM}$ ). It is located $24 \mathrm{~km}$ northeast of Bozeman, MT, USA on a windswept ridge at $2324 \mathrm{~m}$ 
above sea level at $45.7830 \mathrm{~N}, 110.7776 \mathrm{~W}$. The site served as the high elevation grassland biome

103 site for the International Biological Program (1964-1974) and hosts the longest-active snow

104 manipulation experiment of which we are aware (Brookshire and Weaver 2015; Yano et al. 2015).

105 The mean annual temperature is $2.3{ }^{\circ} \mathrm{C}$ and the mean annual precipitation is $981 \mathrm{~mm}$ as estimated

106 by daymet (Thornton et al. 2014). Vegetation is dominated by Idaho fescue (Festuca idahoensis)

107 with increasing cover of the invasive Kentucky bluegrass (Poa pratensis) and soils are loamy-

108 typic cryoborolls (Yano et al. 2015; Weaver and Collins 1977). The study area has been fenced

109 against cattle since the 1930s but is available for forage by wild large ungulates (e.g. mule deer

110 (Odocoileus hemionus) and elk (Cervus canadensis)) and smaller subalpine animals including

111 marmot (Marmota caligata), deer mouse (Peromyscus maniculatus), northern pocket gopher

112 (Thomomys talpoides), and more.

114 Eddy covariance and micrometeorological instrumentation

115 A 3-m tall tripod tower was installed on September 30, 2016, to host eddy covariance and 116 micrometeorological instrumentation (Figure A1). Measurements became available on October 1,

117 2016. Eddy fluxes were measured using a three-dimensional sonic anemometer (CSAT-3,

118 Campbell Scientific, Logan, UT, USA) mounted at $153 \mathrm{~cm}$ above ground level and an enclosed

119 infrared gas analyzer (EC-155 Campbell Scientific) - both recording at $10 \mathrm{~Hz}$ to a CR6 datalogger

120 (Campbell Scientific) - as part of a CPEC300 eddy covariance system. Air temperature (TA) and

121 relative humidity were measured using an HMP45C (Vaisala, Vantaa, Finland) at $200 \mathrm{~cm}$ and used

122 to calculate the atmospheric vapor pressure deficit (VPD). Incident and outgoing short- and

123 longwave radiation were measured using an NR01 net radiometer (Hukseflux, Delft, The

124 Netherlands) at $176 \mathrm{~cm}$. Outgoing longwave radiation observations were used to estimate the 
125 radiometric surface temperature (Tsurf) using the Stefan-Boltzmann equation, assuming a view

126 factor of unity and an emissivity of 0.98 to account for all surfaces observed by the radiometer

127 including grass, bare ground, and snow (Snyder et al. 1998). The shortwave albedo (ALB) was

128 calculated as the ratio of outgoing to incident shortwave radiation, and we use the median of

129 measurements taken between 1100 and 1300 local time to minimize solar zenith angle effects. The

130 normalized difference vegetation index (NDVI) and photochemical reflectance index (PRI) were

131 measured at $176 \mathrm{~cm}$ using Spectral Reflectance Sensors (Decagon (now METER), Pullman, WA,

132 USA). We likewise use the median of measurements taken between 1100 and 1300 to calculate

133 daily values. Soil heat flux (G) was measured using two HFP01SC heat flux plates (Hukseflux) at

$13410 \mathrm{~cm}$ below the soil surface. Three CS650 soil temperature (Tsoil) and moisture content (SWC)

135 sensors (Campbell Scientific) were positioned horizontally at 10, 20, and $40 \mathrm{~cm}$ below the soil

136 surface to account for a rooting depth observed to be at least $50 \mathrm{~cm}$. An additional CS650 was

137 positioned vertically to make an integrated measurement of the top $30 \mathrm{~cm}$ of soil. We present

138 measurements from the sensor at $10 \mathrm{~cm}$ to characterize conditions near the surface including

139 potential freezing. An SR50 sonic distance sensor (Campbell Scientific) was pointed downward at

$140146 \mathrm{~cm}$ to measure distance to surface; we use the median observation from each day to

141 characterize vegetation height or snow depth (h). Micrometeorological observations were

142 measured every second, averaged to half-hour periods, and saved to a CR1000 datalogger

143 (Campbell Scientific). A list of abbreviations is presented in Table 1.

145 Eddy covariance data processing

146 Half-hourly measurements of the eddy flux of carbon dioxide (Fc), latent heat flux (LE), sensible

147 heat flux $(\mathrm{H})$, and momentum flux were calculated using EddyPro (LiCor, Lincoln, Nebraska, 
USA). To calculate fluxes, we used double rotation (Kaimal and Finnigan 1994) - rather than the planar fit method - due to rapid changes in canopy and snow height, as well as block averaging, covariance maximization for time lag detection, and high- and low-pass filters (Moncrieff et al. 2005; Moncrieff et al. 1997). Spike removal was performed as described by Vickers and Mahrt (1997) and defined as more than 3.5 standard deviations from the mean mixing ratio for water vapor and carbon dioxide and 5 standard deviations for vertical wind velocity. Fluxes that did not

154 pass the Mauder and Foken (2011) quality control tests were excluded from the analysis. We assumed that storage of carbon dioxide below the $153 \mathrm{~cm}$ instrument height was negligible such that Fc approximates the net ecosystem exchange of carbon dioxide (NEE). Open access data from US-BMM are published on the Ameriflux website at https://ameriflux.lbl.gov/sites/siteinfo/US$\underline{\text { BMM }}$ (Stoy, 2021).

NEE was partitioned into its components, gross primary productivity (GPP) and ecosystem respiration (RE), using REddyProc (Wutzler et al. 2018). We explored flux partitioning methods

161 that use nighttime flux measurements (Reichstein et al. 2005) and both daytime nighttime and daytime flux measurements (Lasslop et al. 2010) to model NEE given that results from these two methods can differ and impact the interpretation of GPP (Reichstein et al. 2012; Stoy et al. 2006). air temperature as described in Reichstein et al. (2005):

$$
R E=R_{R e f} \exp \left[E_{0}\left(\frac{1}{T_{R e f}-T_{0}}-\frac{1}{T-T_{0}}\right)\right.
$$

167 where $R_{\text {Ref }}\left(\mu \mathrm{mol} \mathrm{CO} \mathrm{Cm}^{-2} \mathrm{~s}^{-1}\right)$ is the reference respiration at the reference temperature, $T_{\text {Ref }}$ is set 168 to $15^{\circ} \mathrm{C}$ and $T_{0}$ is set to $-46.02{ }^{\circ} \mathrm{C}$ (Wutzler et al. 2018; Reichstein et al. 2005; Lloyd and Taylor 169 1994). Nighttime data are constrained between local sunrise and sunset and when incoming 170 shortwave radiation is less than $10 \mathrm{~W} \mathrm{~m}^{-2} . E_{0}$ is estimated using 15 -day windows and aggregated 
171 to an annual estimate, and a temporally varying $R_{R e f}$ is estimated using the annually aggregated $E_{0}$

172 (Wutzler et al. 2018). The relationship developed from nighttime data is extrapolated using air

173 temperature measurements during the day to estimate daytime RE and GPP is calculated as: GPP

$174=\mathrm{RE}-\mathrm{NEE}$.

176 light response curve following (Lasslop et al. 2010):

$$
N E E=\frac{\alpha R_{g} \beta}{\beta+\alpha R_{g}}+\gamma=\frac{\alpha R_{g} \beta}{\beta+\alpha R_{g}}+R_{R e f} \exp \left[E_{0}\left(\frac{1}{T_{R e f}-T_{0}}-\frac{1}{T-T_{0}}\right)\right]
$$

178 where $\alpha\left(\mu \mathrm{mol} \mathrm{CO} \mathrm{J}^{-1}\right)$ is the canopy light use efficiency before light saturation is reached, $\beta$ $179\left(\mu \mathrm{mol} \mathrm{CO} \mathrm{CO}^{-2} \mathrm{~s}^{-1}\right)$ is the maximum $\mathrm{CO}_{2}$ uptake rate at light saturation, $R_{g}$ is the incoming 180 shortwave radiation at the surface $\left(\mathrm{W} \mathrm{m}^{-2}\right)$, and $\gamma\left(\mu \mathrm{mol} \mathrm{CO}_{2} \mathrm{~m}^{-2} \mathrm{~s}^{-1}\right)$ is RE. $\beta$ in the Lasslop et al. 181 (2010) algorithm is calculated as:

$$
\beta=\beta_{0} \exp \left[-k\left(V P D-V P D_{0}\right)\right] \text { if } V P D>V P D_{0}
$$

183 where $\beta_{0}$ is the maximum $\mathrm{CO}_{2}$ uptake rate at light saturation under ideal VPD and $\beta=\beta_{0}$ when

$184 \mathrm{VPD} \leq V P D_{0} . V P D_{0}$ is set as $10 \mathrm{hPa} . E_{0}$ is estimated using nighttime data in moving windows and

185 the resulting estimates are smoothed (Wutzler et al. 2018). Prior estimates for $R_{R e f}$ are also 186 estimated using nighttime data for the moving window with smoothed $E_{0}$. Finally, the parameters $187\left(R_{R e f}, \alpha, \beta_{0}, k\right)$ are estimated using daytime data for each time window (Wutzler et al. 2018). The first term on the right-hand side of the equation (2) represents GPP and we fit the

189 equation $G P P=\frac{\alpha R_{g} \beta}{\beta+\alpha R_{g}}$ using nonlinear least squares (nls) in R (R Core Team, 2021) to calculate $190 \beta$ for periods before and between snow events. We use ANOVA with Tukey's HSD test to 191 calculate significant differences in $\beta$ among different measurement periods. Latent heat flux (LE) 
192

193

194

195

196

197

198

199

200

201

202

203

204

205

206

207

208

209

210

211

$$
G C C=\frac{G_{D N}}{R_{D N}+G_{D N}+B_{D N}}
$$

212 and

213

and sensible heat flux $(\mathrm{H})$ were also gapfilled using REddyProc, which applies mean diurnal sampling to estimate missing values of these quantities (Falge et al. 2001).

Vegetation indices from Phenocam and MODIS

A 5 MP NetCam SC phenocam (StarDot Technologies, Buena Park, CA) was installed 75 m SW of the eddy covariance tower in August 2015. The phenocam pointed north and captured an area that is typically upwind of the tower given the predominantly westerly winds (Figure 1). Observations were available for November and December 2016 after eddy covariance observations began, and for 2017 until early October.

Hourly daytime .jpg images were automatically uploaded to the PhenoCam website (https://phenocam.sr.unh.edu/webcam) where they are freely available. For this analysis we use the phenocam data product of (Seyednasrollah et al. 2019) as described in (Richardson et al. 2018) and (Seyednasrollah et al. 2019). Briefly, the phenocam analysis involves choosing a region of interest (ROI) for the main grass portion of each image as demonstrated for a single image in Figure 1. Digital numbers (DN) for the red, green, and blue (RGB) layers were then extracted from the ROI of each image and used to calculate the green chromatic coordinate (GCC) and red chromatic coordinate (RCC), which have proven effective for describing phenological variability (Richardson et al. 2009, 2007) while minimizing the effects of variable scene illumination, noting that the RCC has proven particularly useful for identifying snow (Liu et al. 2020):

$$
R C C=\frac{R_{D N}}{R_{D N}+G_{D N}+B_{D N}}
$$


214 For this analysis we use the daily 90th percentile values of the GCC and RCC as recommended by

215 (Richardson et al. 2018) to minimize the effects of diurnal variability in illumination geometry and

216 its effects on phenocam imagery.

217 To explore late-season greenness from spaceborne platforms, we calculated NDVI for the

218 pixel corresponding to the tower $(45.784884,-110.777995)$ using the MCD43A4 v006

219 Terra+Aqua Nadir BRDF-Adjusted Reflectance daily 500 m product (Schaaf and Wang 2015;

220 Campagnolo et al. 2016). The NDVI was calculated as:

$$
N D V I_{M O D I S}=\frac{\rho_{N I R}-\rho_{R e d}}{\rho_{N I R}+\rho_{\text {Red }}}
$$

222 Where $\rho_{\text {NIR }}$ is the MCD43A4 surface reflectance in near-infrared wavelengths $(841-876 \mathrm{~nm})$ and

$223 \rho_{\text {Red }}$ is the MCD43A4 surface reflectance in red wavelengths $(620-670 \mathrm{~nm})$.

\section{Results}

226 We first present micrometeorological, surface-atmosphere exchange, and radiometric data for the

2272016 study period, which we define as October 1 when measurements began until November 12

228 when flux measurements became unavailable due to power system failure. We follow the 2016

229 results with the 2017 findings and define a study period of September 10 - four days before first

230 snowfall for consistency with the 2016 study period - until November 12 . Measurements were

231 available until December 12, 2017, but with consistent snow cover after October 29 as we detail

232 later. We then discuss measurements made during the summer of 2017 for comparison with

233 autumn measurements and describe MODIS observations for the years prior to, during, and after

234 the eddy covariance study period. 
$237 \mathrm{G}$ decreased from a maximum of $34 \mathrm{~W} \mathrm{~m}^{-2}$ when measurements began on October 1, 2016 (Figure

238 2) and did not exhibit a diurnal cycle four days later, when Tsurf was equal to or less than $0{ }^{\circ} \mathrm{C}$,

239 SWC increased from $30 \%$ to $35 \%$, ALB increased to values greater than $50 \%$, NDVI decreased to

240 less than 0 , and $\mathrm{h}$ (here suggesting changes in snow height) increased from 0.12 to $0.20 \mathrm{~m}$ (Figure

2413 ). These observations are consistent with snow presence, and we subsequently use

242 micrometeorological, radiometric, and flux observations to determine snow presence or absence

243 (Table 2). We also use phenocam observations to identify snow periods during the parts of 2017

244 when images were available (e.g., Figure 1).

245 NEE exhibited a distinct diurnal signal before the first snowfall event of autumn, 2016, that

246 was dampened when snow was present (Figure 4). The nighttime partitioning approach (Reichstein

247 et al. 2005) estimated that GPP was usually no greater than $2 \mu \mathrm{mol} \mathrm{m} \mathrm{s}^{-1}$ during peak daytime

248 periods when snow was present. The daytime partitioning approach (Lasslop et al. 2010)

249 frequently estimated a GPP of $\sim 2 \mu \mathrm{mol} \mathrm{m} \mathrm{m}^{-2} \mathrm{~s}^{-1}$ during peak daytime periods when snow was present

250 (Figure A2). From these observations, nighttime partitioning is arguably more conservative for

251 estimating GPP in the presence of snow. We focus the rest of our analysis on GPP and RE values

252 obtained using the Reichstein et al. (2005) nighttime partitioning method.

We identified four snow periods in 2016 (Table 2, Figures 2-4) before measurements

254 became unavailable for the rest of the year on November 12. After the first snowfall, Tsoil was

255 lower and SWC higher than the pre-snow period for the remainder of the 2016 study period. Tsoil

256 remained lower than $6{ }^{\circ} \mathrm{C}$ after first snowfall for the remainder of the study period, but TA

257 consistently reached $10{ }^{\circ} \mathrm{C}$ or greater and Tsurf was frequently greater than $20{ }^{\circ} \mathrm{C}$ during midday

258 periods between snowfall events. Mid-day reflectance measurements (NDVI and PRI) did not

259 differ for the period before snow and the inter-snow periods (Figure 3). 
Mid-day GPP decreased from $\sim 6 \mu \mathrm{mol} \mathrm{m}{ }^{-2} \mathrm{~s}^{-1}$ before the first snowfall to between 2 and 4

$261 \sim \mu \mathrm{mol} \mathrm{m}{ }^{-2} \mathrm{~s}^{-1}$ after the fourth snow event (Figure 4). The light response curve analysis indicated

262 no significant difference in $\beta$ for the period before snow and first two inter-snow periods, which

263 averaged $6.64 \mu \mathrm{mol} \mathrm{CO} \mathrm{m}^{-2} \mathrm{~s}^{-1}$ (Figure 5, Table 2). $\beta$ during the third inter-snow period was

264 significantly lower $\left(4.62 \mu \mathrm{mol} \mathrm{CO} \mathrm{Cm}^{-2} \mathrm{~s}^{-1}\right)$ and the fourth significantly lower still $\left(3.44 \mu \mathrm{mol} \mathrm{CO}_{2}\right.$

$265 \mathrm{~m}^{-2} \mathrm{~s}^{-1}$ ) (Table 2). Respiration decreased from $3 \mu \mathrm{mol} \mathrm{m} \mathrm{m}^{-2} \mathrm{~s}^{-1}$ to $1 \mu \mathrm{mol} \mathrm{m}^{-2} \mathrm{~s}^{-1}$ throughout the 2016

266 autumn measurement period (Figure 4). As a consequence, the ecosystem was a net sink of $\mathrm{CO}_{2}$

267 (i.e., NEE was negative) during midday of all snow-free periods during the measurement record

268 in 2016 (Figure 4) but was a source of $\mathrm{C}$ to the atmosphere during other times of day and lost 50

$269 \mathrm{~g} \mathrm{C} \mathrm{m}^{-2}$ from October 2 until November 12, 2016.

271 Observations during autumn, 2017

272 Autumn, 2017 was characterized by two weeks of snow presence from September 15 until

273 September 29, after which measurements indicated a three-day snow-free period, followed by four

274 days of snow, nearly a week without snow, and additional snow and no-snow periods of less than

275 one week in duration before consistent snow presence began on October 29. We determined these

276 dates using a combination of G, Tsurf, and turbulent flux observations and phenocam observations

277 when available, and we discuss challenges in determining snow presence in the Discussion.

279 fell in 2016 (Figure 2) - and increased to 35\% after the first 2017 snow event. TA intermittently

280 reached nearly $20^{\circ} \mathrm{C}$ during the periods between snow in 2017, as did Tsurf, and Tsoil remained

281 above $0{ }^{\circ} \mathrm{C}$ until November 12 when the study period ended for consistency with data availability

282 during 2016 (Figure 6). As opposed to 2016, NDVI stayed consistently at or below 0 and ALB 
283 remained above 50\% during the periods between snow presence (Figure 7), which we identified

284 largely using G, Tsurf, and turbulent flux observations as noted. The phenocam was active during

285 the first and second snowfall and melt periods in 2017, and RCC declined sharply from nearly 0.6

286 to less than 0.35 after the first snow event (Figure 8). RCC recovered to values approaching 0.4

287 during the first inter-snow period and nearly 0.45 after the second snow period after which

288 measurements became unavailable. GCC was less sensitive to snow presence and absence (Figure

289 8).

290 Maximum daily GPP before and after the first two snow events was on the order of 3 $291 \mu \mathrm{mol} \mathrm{m} \mathrm{m}^{-2} \mathrm{~s}^{-1}$ (Figure 9); recall that light-saturated GPP (i.e., $\beta$ ) reached values of $\sim 6 \mu \mathrm{mol} \mathrm{m}^{-2} \mathrm{~s}^{-1}$

292 in 2016 (Figures 4 and 5). $\beta$ was $2.47 \mu \mathrm{mol} \mathrm{m}^{-2} \mathrm{~s}^{-1}$ before snowfall. Like 2016, $\beta$ was not

293 significantly different for the first two inter-snow periods but was significantly less than the before-

294 snow period by the third inter-snow period, when it decreased to $1.50 \mu \mathrm{mol} \mathrm{m}^{-2} \mathrm{~s}^{-1}$ (Figure 10 ,

295 Table 2). As opposed to 2016, NEE was rarely less than $0 \mu \mathrm{mol} \mathrm{m} \mathrm{m}^{-2} \mathrm{~s}^{-1}$ such that the ecosystem

296 was almost continuously losing carbon after the first snowfall in 2017 (Figures 4 and 9). The

297 ecosystem was a consistent net source of $\mathrm{C}$ to the atmosphere as a consequence, with the possible

298 exception of two relatively large net carbon uptake events in early November that are inconsistent

299 with micrometeorological observations during this time that suggest snow presence. The

300 ecosystem lost $51 \mathrm{~g} \mathrm{C} \mathrm{m}^{-2}$ during the period from October 1 - November 12, 2017, similar to 2016.

301 There was a notable increase in NEE and RE from values less than $2 \mu \mathrm{mol} \mathrm{m} \mathrm{m}^{-2} \mathrm{~s}^{-1}$ to values greater

302 than $2 \mu \mathrm{mol} \mathrm{m} \mathrm{m}^{-2} \mathrm{~s}^{-1}$ around September 17, 2017, a snow-covered period when TA was greater than

$3030{ }^{\circ} \mathrm{C}$, SWC increased from 10 to $20 \%$, LE reached values of nearly $100 \mathrm{~W} \mathrm{~m}^{-2}$, and $\mathrm{H}$ was negative

304 during the day indicating heat flux into the snowpack (Figures 6 and 9). 
307 Eddy covariance and micrometeorological measurements were available from mid-July 2017

308 onward (Figure 11) and we present these observations to place the 2017 autumn measurements in

309 context. Light-saturated GPP (i.e., $\beta$ ) was $18.6 \mu \mathrm{mol} \mathrm{m}^{-2} \mathrm{~s}^{-1}$ during late July (Figure 12), already

310 decreased to $9.02 \mu \mathrm{mol} \mathrm{m}^{-2} \mathrm{~s}^{-1}$ as drought progressed in early August, decreased further to 6.16

$311 \mu \mathrm{mol} \mathrm{m} \mathrm{m}^{-2} \mathrm{~s}^{-1}$ during late August, and reached $\sim 3 \mu \mathrm{mol} \mathrm{m}^{-2} \mathrm{~s}^{-1}$ during early September as noted

312 above (Figure 10, Table 2). In other words, $\beta$ was approximately $1 / 6^{\text {th }}$ of its maximum observed

313 value in summer before snowfall in 2017.

316 We analyzed only those NDVI

317 measurements at lower values that are consistent with full or patchy snow cover. A notable increase

318 (i.e., greening) in NDVI MODIS $_{\text {occurred in }} 2015$ from 0.45 on October 7 to 0.5 on October 27, and

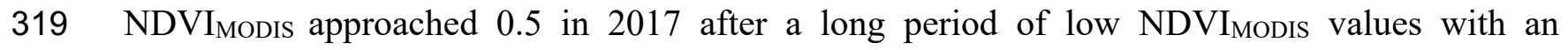

320 inconsistent vegetation signal that began on September 12 (Figure 13). Other years, namely 2016

321 and 2019, did not demonstrate any late season increase in NDVI $_{\text {MODIS }}$ although measurements in

3222016 rarely dropped below 0.4 during the latter part of the calendar year.

324 Discussion

325 Overview: Is photosynthesis in mountain meadows resistant or resilient to autumn snow events?

326 Decades of research at the Bangtail Mountain Meadow study site and communication with the

327 Montana ranching community has led to the suggestion that canopy photosynthesis would

328 "recover" after drought-breaking autumn precipitation, which often falls as snow. The ecosystem 
was not likely under drought stress before snow fell in 2016 as SWC was 30\% (Figure 3) but was only $\sim 10 \%$ before snowfall during 2017 (Figure 7) and thus well below the point at which grasses are often considered drought stressed (Rodríguez-Iturbe and Porporato 2007; RodriguezIturbe et al. 1999). Observations from 2017, a drier year, indicate that GPP was rarely greater during inter-snow periods than it was before snowfall despite added moisture (Figures 4 and 9), and $\beta$ was not significantly different before or after the first two snow events in either year (Figures in the recovery of GPP after snow melt (Figures 4 and 9). In other words, rather than a recovery of photosynthetic function and thereby resilience to snow disturbances, our observations suggest that the vegetation probably never lost photosynthetic function under snow in the first place, at

339 least after the first two snow events. Instead, observations are consistent with the notion that 340 autumn snowfall and melt is a minor disturbance against which mountain meadow photosynthesis 341 is resistant.

343 (Tieszen 1973; Tieszen and Sigurdson 1973; Skinner 2007), and some grasses maintain 344 photosynthesis under cold and dark conditions that simulate the subnivean environment (Höglind, 345 Hanslin, and Mortensen 2011). Our observations suggest finite GPP even in the presence of snow

346 (e.g., Figures 4 and 9). At the same time the study site is vegetatively diverse, and it is difficult to

347 establish with certainty that grasses are the primary contributor to ecosystem-scale GPP during 348 and after snow events. Some mosses can photosynthesize under snow (Street et al. 2012) and are 349 characterized by light-saturated photosynthesis (e.g., $\beta$ ) ranging from nearly 0 to $7 \mu \mathrm{mol} \mathrm{m}^{-2} \mathrm{~s}^{-1}$ 350 (Van Gaalen, Flanagan, and Peddle 2007; Street et al. 2012; Skre and Oechel 1981), similar to our 351 observations during periods between snow events in 2016 (Figure 5). At the same time, moss cover 
352 at the site is sparse and likely insufficient to explain $\beta$ observations of up to $7 \mu \mathrm{mol} \mathrm{m} \mathrm{m}^{-2} \mathrm{~s}^{-1}$ on a

353 ground area basis. Instead, photosynthesizing vascular vegetation - that often occurs toward the

354 bottom of grass canopies in autumn (Migliavacca et al. 2011) - is more consistent with available

355 observations (see Figure A1). These patterns are often difficult to discern with phenocams that

356 point laterally (Figures 1 and 8) (Migliavacca et al. 2011). The tower-mounted NDVI sensors point

357 downward, and measurements can exceed 0.2 during periods between snow (e.g. Figure 2). These

358 are low values of NDVI for grass sites (Gamon et al. 1995) that are consistent with the small carbon

359 fluxes that we observe during these times (Figures 4, 5, 9, and 10). Carbon uptake is also lower at

360 the study site than most global grasslands; for example, peak light-saturated NEE at $1500 \mu \mathrm{mol} \mathrm{m}^{-}$

$361{ }^{2} \mathrm{~s}^{-1}$ PPFD following the approach of (Ruimy et al. 1995) is $10.9 \mu \mathrm{mol} \mathrm{m} \mathrm{m}^{-2} \mathrm{~s}^{-1}$ at our study site,

362 versus a global average of $25.5 \mu \mathrm{mol} \mathrm{m} \mathrm{m}^{-1}$ (Gilmanov et al. 2010), as would be expected for our

363 relatively cold study site.

364 Our measurements gave no evidence that mountain meadow GPP was any greater after

365 snow than before snow, even when more moisture and favorable growing conditions occurred after

366 snowmelt periods as seen in 2017. It was unclear if there was any flush of new leaves, but no

367 observable height growth between snow events occurred (Figures 3 and 7). We cannot say for

368 certain which grass species were responsible for photosynthesis after snow, but observations in

369 Bozeman suggest that the invasive Poa pratensis rather than native Festuca idahoensis is more

370 likely to remain green in the cold season, with consequences for ecosystem function as invasive

371 grasses continue to establish at the study site. Species-level measurements at the Bangtail

372 Mountain Meadow would likely require careful in-person measurements during uncertain travel

373 conditions and/or high-resolution imagery that is increasingly used in conjunction with machine

374 learning approaches to estimate grass growth and phenology (Oliveira et al. 2020; Viljanen et al. 
375 2018). A comprehensive monitoring framework would require species-level studies of the

376 response of the ecosystem to climate variability and would help reconcile population and

377 community dynamics that we were unable to observe with certainty in the present study.

379 Ecosystem dynamics during snow presence

380 A notable event occurred around September 17, 2017, when snow was present, but TA reached 381 nearly $10{ }^{\circ} \mathrm{C}$ and $\mathrm{H}$ became negative, indicating heat exchange into the snowpack and melt (Stoy 382 et al. 2018), but Tsurf remained at or near $0{ }^{\circ} \mathrm{C}$ indicating that snow did not fully melt. SWC 383 increased from $10 \%$ to $20 \%$ during this event and NEE also increased, suggesting enhanced soil 384 respiratory activity. We posit that the snowpack was melting during this period but did not fully 385 ablate, and the corresponding input of soil water enhanced respiratory activity owing to the Birch

386 effect (Jarvis et al. 2007). We further speculate that the soil water input and observations of 387 respiratory fluxes were synchronized in time because of pressure pumping (i.e., enhanced 388 diffusion) through snow at this characteristically windy montane site (Rains et al. 2016; Bowling 389 and Massman 2011; Berryman et al. 2018). Decadal snow fence observations at the site that 390 suggest that enhanced snowpack duration depletes soil C, N and P (Yano et al. 2015; Weaver and 391 Collins 1977), but the microbial mechanisms of potential under-snow Birch effects in ecosystems 392 that receive drought-breaking snow need to be substantiated with direct observations of soil 393 biogeochemistry.

395 The challenges of patchy snow

396 We used micrometeorological and radiometric observations to identify snow presence using 397 instruments on or in the vicinity of the eddy covariance tripod tower, confirmed with phenocam 
measurements when available (Figures 1, 2, 3, 6, 7 and 8). Turbulent fluxes arise from the eddy covariance flux footprint, which was often in the scene of the phenocam that measured the area immediately to the west of the tower, the dominant wind direction (Figure 1). The physical

401 infrastructure of the tower will cause snow deposition and alter snowpack characteristics; and we

402 suspect that this is the reason that the 2017 melt events identified using micrometeorological and

403 flux observations (Figures 6 and 9) differed from the radiometers that suggested snow was still

404 present (Figure 7). In other words, snow presence was often patchy (e.g., Figure 1) and influenced

405 by the measurement infrastructure itself, by slowing wind speed to deposit snow. This leads to an

406 observational challenge of identifying what is 'snow-covered' for the purpose of ecosystem-scale

407 studies. Going forward, we propose a tripartite classification system with no snow, full snow, and

408 patchy snow may be the best approach for studying the impacts of snow at the plot or flux footprint

409 scale, which remains a challenge for observation systems (Kosmala et al. 2018). During melt,

410 dynamic changes to the snow-covered area across space and time are being sampled by a dynamic

411 flux footprint (Chu et al. 2021), both of which require extensive quantification that can include

412 substantial uncertainty. From our analysis such an observation system could not rely on tower-

413 mounted instrumentation alone due to tower infrastructure impacts on snow dynamics. In this case

414 a tower within the field of view of the phenocam would have been preferred (Stoy et al. 2021).

Remote sensing

417 Remote sensing plays an important role in understanding the physiology of global ecosystems, 418 especially in areas that are difficult to access. MODIS has been found to provide reasonable 419 measurements of vegetation physiology for grasslands of the Northern Rockies (St. Peter et al. 420 2018). Differences are to be expected amongst RS sensors (Rossi et al. 2019) and among different 
421 grassland sites (Wohlfahrt et al. 2010), and the coarse spatial scale and diurnal return interval of

422 MODIS gave very different NDVI results than the tower-mounted instrumentation at our site

423 (Figures 3, 7, and 13). Recent advances to geostationary satellite technology - for example

424 enhanced observational capacities in the visible and near infrared from the Advanced Baseline

425 Imager on the Geostationary Operational Environmental Satellite (Khan et al. 2021) - provide new

426 opportunities for understanding snow duration (Romanov and Tarpley 2004; Romanov et al. 2000)

427 and vegetation production after melt. Enhanced observational systems at multiple scales in space

428 including tower-mounted instruments, phenocams, unpiloted aerial vehicles, and satellite remote

429 sensing will further improve our understanding of autumn phenological changes in global

430 ecosystems (Gallinat et al. 2015).

431

$432 \quad$ Implications and future studies

433 Grass photosynthesis is notably resilient to small disturbances. If sufficient soil moisture is 434 available for regrowth photosynthesis tends to reestablish rapidly following harvesting (Novick et

435 al. 2004; Stoy et al. 2008), grazing (Parsons et al. 1983), and heat waves (Hoover, Knapp, and

436 Smith 2014), often dependent on species and growth form (Cremonese et al. 2017). Grass

437 photosynthesis also tends to establish rapidly after snowmelt in spring (Julitta et al. 2014; Vitasse

438 et al. 2017), which we were not able to observe at our site due to equipment and power failure over

439 winter. However, our observations suggest that mountain meadow photosynthesis is resistant to

440 autumn snowfall which appears to be a minor disturbance for events up to two weeks in duration.

441 The resistance of grass vegetation to extreme climate conditions is another matter as extreme

442 drought (Hoover, Knapp, and Smith 2014) and desertification (D’Odorico et al. 2013) threaten

443 grasslands worldwide. 
445 and productivity of subalpine meadows (Canaday and Fonda 1974). We argue that spring

446 snowmelt (or summer, depending on site) is only one of often two periods of importance for

447 montane grassland phenology and function, the second being the transition to the full snowpack in

448 winter, which may contain multiple snowfall and melt periods that can bring needed moisture to

449 mountain meadows (Brookshire and Weaver 2015). Montane grass photosynthesis appears to be

450 resistant at the ecosystem-scale, at least for the first two snow events in our study. Enhanced

451 observational systems that consider population, community, and ecosystem-scale responses to

452 ongoing climate changes during autumn (Gallinat et al. 2015) will improve our understanding of

453 the ecosystem services that montane grasslands provide across all seasons.

\section{Acknowledgments}

456 We acknowledge the Indigenous Nations on whose ancestral lands the study took place and 457 recognize that the infrastructure used for this project was built on Indigenous land. We recognize 458 multiple Indigenous Nations as past, present, and future caretakers of this land whose stewardship

459 of the region was interrupted by their physical removal under the 1830 Indian Removal Act and 460 through US Assimilation policies explicitly designed to eradicate Indigenous language and ways 461 of being until the 1970s.

463 cooperative agreement OIA-1632810. We also thank the Montana State University College of 464 Agriculture and the University of Wisconsin for financial assistance and Dr. James Irvine for 465 extensive technical support. Adam Cook, Dr. Geneva Chong, Justin Gay, Dr. Bill Kleindl, F. 466 Aaron Rains, Dr. Angela Tang, and Bill Vandenberg provided additional technical support for 
467 which we are grateful., And we thank Dr. Susanne Wiesner for insightful comments on the

468 manuscript. Phenocam research was supported by Colorado State University and the AmericaView

469 program (grants G13AC00393, G11AC20461, G15AC00056) with equipment and deployment

470 sponsored by the Department of Interior North Central Climate Science Center.

\section{References}

473 Batbaatar, Amgaa, Edward W. Bork, Tanner Broadbent, Mike J. Alexander, James F. Cahill, and

Berryman, E. M., J. M. Frank, W. J. Massman, and M. G. Ryan. 2018. "Using a Bayesian

Bowling, D. R., and W. J. Massman. 2011. "Persistent Wind-Induced Enhancement of Diffusive

$$
\text { G04006. https://doi.org/10.1029/2011jg001722 }
$$


490 Brookshire, E. N. J., and T. Weaver. 2015. "Long-Term Decline in Grassland Productivity

491 Driven by Increasing Dryness." Nature Communications 6: 7148.

492 https://doi.org/10.1038/ncomms 8148

493 Campagnolo, Manuel L., Qingsong Sun, Yan Liu, Crystal Schaaf, Zhuosen Wang, and Miguel O. Román. 2016. "Estimating the Effective Spatial Resolution of the Operational BRDF, Albedo, and Nadir Reflectance Products from MODIS and VIIRS.” Remote Sensing of Environment 175 (March): 52-64. https://doi.org/10.1016/j.rse.2015.12.033

Canaday, B. B., and R. W. Fonda. 1974. "The Influence of Subalpine Snowbanks on Vegetation Pattern, Production, and Phenology." Bulletin of the Torrey Botanical Club 101: 340-350. https://doi.org/10.2307/2484957.

Chu, Housen, Xiangzhong Luo, Zutao Ouyang, W. Stephen Chan, Sigrid Dengel, Sébastien C. 301-302 (108350): 108350. https://doi.org/10.1016/j.agrformet.2021.108350

Cremonese, Edoardo, Gianluca Filippa, Marta Galvagno, Consolata Siniscalco, Ludovica Oddi, Umberto Morra di Cella, and Mirco Migliavacca. 2017. "Heat Wave Hinders Green Wave: The Impact of Climate Extreme on the Phenology of a Mountain Grassland.” Agricultural and Forest Meteorology 247: 320-30. https://doi.org/10.1016/j.agrformet.2017.08.016

D’Odorico, Paolo, Abinash Bhattachan, Kyle F. Davis, Sujith Ravi, and Christiane W. Runyan. 2013. "Global Desertification: Drivers and Feedbacks." Advances in Water Resources 51: 326-44. https://doi.org/10.1016/j.advwatres.2012.01.013 
$32 \mathrm{pp}$.

514 Falge, Eva, Dennis Baldocchi, Richard Olson, Peter Anthoni, Marc Aubinet, Christian

515 Bernhofer, George Burba, et al. 2001. "Gap Filling Strategies for Long Term Energy Flux

516 Data Sets.” Agricultural and Forest Meteorology. https://doi.org/10.1016/s0168-

518 Gallinat, Amanda S., Richard B. Primack, and David L. Wagner. 2015. “Autumn, the Neglected

519 Season in Climate Change Research." Trends in Ecology \& Evolution 30 (3): 169-76.

$520 \quad$ https://doi.org/10.1016/j.tree.2015.01.004

521 Gamon, John A., Christopher B. Field, Michael L. Goulden, Kevin L. Griffin, Anne E. Hartley,

522 Geeske Joel, Josep Penuelas, and Riccardo Valentini. 1995. "Relationships Between NDVI,

523 Canopy Structure, and Photosynthesis in Three Californian Vegetation Types.” Ecological

$524 \quad$ Applications 5: 28-41. https://doi.org/10.2307/1942049

525 Gilmanov, Tagir G., L. Aires, Z. Barcza, V. S. Baron, L. Belelli, J. Beringer, D. Billesbach, et al.

526 2010. "Productivity, Respiration, and Light-Response Parameters of World Grassland and

527 Agroecosystems Derived from Flux-Tower Measurements.” Rangeland Ecology \&

528 Management 63: 16-39. https://doi.org/10.2111/rem-d-09-00072.1

529 Harpold, Adrian, Paul Brooks, Seshadri Rajagopal, Ingo Heidbuchel, Angela Jardine, and Clare

530 Stielstra. 2012. "Changes in Snowpack Accumulation and Ablation in the Intermountain

531 West.” Water Resources Research 48: W11501. https://doi.org/10.1029/2012wr011949

532 Höglind, Mats, Hans M. Hanslin, and Leiv M. Mortensen. 2011. "Photosynthesis of Lolium

533 Perenne L. at Low Temperatures under Low Irradiances.” Environmental and Experimental

534 Botany 70: 297-304. https://doi.org/10.1016/j.envexpbot.2010.10.007

535 Hoover, David L., Alan K. Knapp, and Melinda D. Smith. 2014. "Resistance and Resilience of a 
Grassland Ecosystem to Climate Extremes.” Ecology 95, 2646-2656. https://doi.org/10.1890/13-2186.1

Hufkens, Koen, Trevor F. Keenan, Lawrence B. Flanagan, Russell L. Scott, Carl J. Bernacchi,

539 Eva Joo, Nathaniel A. Brunsell, Joseph Verfaillie, and Andrew D. Richardson. 2016. "Productivity of North American Grasslands Is Increased under Future Climate Scenarios

Hurley, Mark A., Mark Hebblewhite, Jean-Michel Gaillard, Stéphane Dray, Kyle A. Taylor, W. despite Rising Aridity." Nature Climate Change 6 (7): 710-14.

Hurley, Mark A., Mark Hebblewhite, Paul M. Lukacs, J. Joshua Nowak, Jean-Michel Gaillard, and Christophe Bonenfant. 2017. "Regional-Scale Models for Predicting Overwinter Survival of Juvenile Ungulates.” The Journal of Wildlife Management 81(3), 364-378. K. Smith, Pete Zager, and Christophe Bonenfant. 2014. "Functional Analysis of Normalized Consolata Siniscalco, Micol Rossini, et al. 2014. "Using Digital Camera Images to Analyse 
198: 116-125. https://doi.org/10.1016/j.agrformet.2014.08.007

560

561

562

563

564

565

Kaimal, J. C., and J. J. Finnigan. 1994. Atmospheric Boundary Layer Flows: Their Structure and Measurement. Oxford University Press.

Khan, Anam M., Paul C. Stoy, James T. Douglas, Martha Anderson, George Diak, Jason A. Otkin, Christopher Hain, Elizabeth M. Rehbein, and Joel McCorkel. 2021. "Reviews and Syntheses: Ongoing and Emerging Opportunities to Improve Environmental Science Using Observations from the Advanced Baseline Imager on the Geostationary Operational Environmental Satellites.” Biogeosciences 18 (13): 4117-41. https://doi.org/10.5194/bg-184117-2021

Körner, Christian. 2004. "Mountain Biodiversity, Its Causes and Function.” Ambio 33: 11-17. https://doi.org/10.1007/0044-7447-33.sp13.11

Körner, Ch, and E. M. Spehn. 2019. Mountain Biodiversity: A Global Assessment. Routledge.

Kosmala, Margaret, Koen Hufkens, and Andrew D. Richardson. 2018. "Integrating Camera Imagery, Crowdsourcing, and Deep Learning to Improve High-Frequency Automated Monitoring of Snow at Continental-to-Global Scales.” PloS One 13 (12): e0209649. https://doi.org/10.1371/journal.pone.0209649

Lasslop, Gitta, Markus Reichstein, Dario Papale, Andrew D. Richardson, Almut Arneth, Alan Barr, Paul Stoy, and Georg Wohlfahrt. 2010. “Separation of Net Ecosystem Exchange into Assimilation and Respiration Using a Light Response Curve Approach: Critical Issues and Global Evaluation.” Global Change Biology 16 (1): 187-208. https://doi.org/10.1111/j.1365-2486.2009.02041.x

Liu, Ying, Chaoyang Wu, Oliver Sonnentag, Ankur R. Desai, and Jian Wang. 2020. "Using the Red Chromatic Coordinate to Characterize the Phenology of Forest Canopy 
Photosynthesis." Agricultural and Forest Meteorology 285: 107910.

Lloyd, J., and J. A. Taylor. 1994. "On the Temperature Dependence of Soil Respiration.” 27(5), 993-1002. https://doi.org/10.1111/gcb.15458

Lundell, Robin, Timo Saarinen, Helena Åström, and Heikki Hänninen. 2008. “The Boreal Dwarf Botany 86: 491-500. https://doi.org/10.1139/b08-022.

Mauder, Matthias \& Thomas Foken. "Documentation and Instruction Manual of the Eddy-

Migliavacca, Mirco, Marta Galvagno, Edoardo Cremonese, Micol Rossini, Michele Meroni, Oliver Sonnentag, Sergio Cogliati, et al. 2011. "Using Digital Repeat Photography and Eddy Covariance Data to Model Grassland Phenology and Photosynthetic $\mathrm{CO}_{2}$ Uptake.”

601 Moncrieff, J. B., J. M. Massheder, H. de Bruin, J. Elbers, T. Friborg, B. Heusinkveld, P. Kabat, 602 S. Scott, H. Soegaard, and A. Verhoef. 1997. "A System to Measure Surface Fluxes of 603 Momentum, Sensible Heat, Water Vapour and Carbon Dioxide.” Journal of Hydrology 188189: 589-611. https://doi.org/10.1016/S0022-1694(96)03194-0 
Moncrieff, John, Robert Clement, John Finnigan, and Tilden Meyers. 2005. “Averaging,

606

607

608

609

610

611

612

613

614

615

616

617

618

619

620

621

622

623

624

625

626

627

Detrending, and Filtering of Eddy Covariance Time Series.” In Handbook of

Micrometeorology: A Guide for Surface Flux Measurement and Analysis, edited by Xuhui

Lee, William Massman, and Beverly Law, 7-31. Dordrecht: Springer Netherlands.

Novick, K. A., P. C. Stoy, G. G. Katul, D. S. Ellsworth, M. B. S. Siqueira, J. Juang, and R. Oren. 2004. "Carbon Dioxide and Water Vapor Exchange in a Warm Temperate Grassland."

Oecologia 138 (2): 259-74. https://doi.org/10.1007/s00442-003-1388-z

Novick, Kimberly A., Darren L. Ficklin, Paul C. Stoy, Christopher A. Williams, Gil Bohrer, A. Christopher Oishi, Shirley A. Papuga, et al. 2016. "The Increasing Importance of Atmospheric Demand for Ecosystem Water and Carbon Fluxes.” Nature Climate Change 6 (11): 1023-27. https://doi.org/10.1038/nclimate3114

Oliveira, Raquel Alves, Roope Näsi, Oiva Niemeläinen, Laura Nyholm, Katja Alhonoja, Jere Kaivosoja, Lauri Jauhiainen, et al. 2020. "Machine Learning Estimators for the Quantity and Quality of Grass Swards Used for Silage Production Using Drone-Based Imaging Spectrometry and Photogrammetry.” Remote Sensing of Environment 246: 111830. https://doi.org/10.1016/j.rse.2020.111830

Parsons, A. J., E. L. Leafe, B. Collett, P. D. Penning, and J. Lewis. 1983. "The Physiology of Grass Production Under Grazing. II. Photosynthesis, Crop Growth and Animal Intake of Continuously-Grazed Swards.” The Journal of Applied Ecology 20: 127-139. https://doi.org/10.2307/2403381

Piao, Shilong, Philippe Ciais, Pierre Friedlingstein, Philippe Peylin, Markus Reichstein, Sebastiaan Luyssaert, Hank Margolis, et al. 2008. "Net Carbon Dioxide Losses of Northern Ecosystems in Response to Autumn Warming." Nature 451 (7174): 49-52. 
https://doi.org/10.1038/nature06444

Rains, F. Aaron, F. Aaron Rains, Paul C. Stoy, Christopher M. Welch, Cliff Montagne, and Brian L. McGlynn. 2016. “A Comparison of Methods Reveals That Enhanced Diffusion Helps Explain Cold-Season Soil $\mathrm{CO}_{2}$ Efflux in a Lodgepole Pine Ecosystem.” Cold Regions Science and Technology 121: 16-24. https://doi.org/10.1016/j.coldregions.2015.10.003

633 Reed, Cody C., Amy G. Merrill, W. Mark Drew, Beth Christman, Rachel A. Hutchinson, Levi Keszey, Melissa Odell, et al. 2021. "Montane Meadows: A Soil Carbon Sink or Source?" Ecosystems 24 (5): 1125-41. https://doi.org/10.1007/s10021-020-00572-x

Reichstein, Markus, Eva Falge, Dennis Baldocchi, Dario Papale, Marc Aubinet, Paul Berbigier, Christian Bernhofer, et al. 2005. "On the Separation of Net Ecosystem Exchange into Assimilation and Ecosystem Respiration: Review and Improved Algorithm.” Global

640 Reichstein, Markus, Paul C. Stoy, Ankur R. Desai, Gitta Lasslop, and Andrew D. Richardson. 2012. "Partitioning of Net Fluxes." In Eddy Covariance: A Practical Guide to Measurement and Data Analysis, edited by Marc Aubinet, Timo Vesala, and Dario Papale, 263-89.

644 Richardson, Andrew D., Bobby H. Braswell, David Y. Hollinger, Julian P. Jenkins, and Scott V. Change Biology 11 (9): 1424-39. https://doi.org/10.1111/j.1365-2486.2005.001002.x M. Gray, Miriam R. Johnston, et al. 2018. “Tracking Vegetation Phenology across Diverse North American Biomes Using PhenoCam Imagery.” Scientific Data 5: 180028. 
https://doi.org/10.1038/sdata.2018.28

Richardson, Andrew D., Julian P. Jenkins, Bobby H. Braswell, David Y. Hollinger, Scott V.

656 Rodriguez-Iturbe, I., P. D’Odorico, A. Porporato, and L. Ridolfi. 1999. “On the Spatial and

Rodríguez-Iturbe, Ignacio, and Amilcare Porporato. 2007. Ecohydrology of Water-Controlled

Rogiers, Nele, Franz Conen, Markus Furger, Reto Stöckli, and Werner Eugster. 2008. "Impact of Applied Climatology 80 (2): 187-203. https://doi.org/10.1007/s00704-004-0099-7

670 Romanov, Peter, and Dan Tarpley. 2004. "Estimation of Snow Depth over Open Prairie

671 Environments Using GOES Imager Observations.” Hydrological Processes 18: 1073-1087. over North America with Multispectral Satellite Data." Journal of Applied Meteorology 39, 1866-1880. https://doi.org/10.1175/1520-0450(2000)039<1866:amosco>2.0.co;2

673 Rossi, Mattia, Georg Niedrist, Sarah Asam, Giustino Tonon, Enrico Tomelleri, and Marc 
Zebisch. 2019. “A Comparison of the Signal from Diverse Optical Sensors for Monitoring Alpine Grassland Dynamics.” Remote Sensing 11 (3): 296. https://doi.org/10.3390/rs11030296

677 Ruimy, A., P. G. Jarvis, D. D. Baldocchi, and B. Saugier. 1995. “CO $\mathrm{CO}_{2}$ Fluxes over Plant

Schaaf, C., and Z. Wang. 2015. "MCD43A4 MODIS/Terra+ Aqua BRDF/Albedo Nadir BRDF Adjusted RefDaily L3 Global 500 M V006.” NASA EOSDIS Land Processes DAAC.

Schmitt, M., M. Bahn, G. Wohlfahrt, U. Tappeiner, and A. Cernusca. 2010. "Land Use Affects

$$
\text { the Net Ecosystem } \mathrm{CO}_{2} \text { Exchange and Its Components in Mountain Grasslands.” }
$$

Seyednasrollah, Bijan, Adam M. Young, Koen Hufkens, Tom Milliman, Mark A. Friedl, Steve

$$
\text { Biogeosciences. https://doi.org/10.5194/bg-7-2297-2010. https://doi.org/10.5194/bg-7- }
$$
https://doi.org/10.1038/s41597-019-0229-9 Agricultural and Forest Meteorology 144: 32-43.

https://doi.org/10.1016/j.agrformet.2007.01.010 
697 Skre, O., and W. C. Oechel. 1981. "Moss Functioning in Different Taiga Ecosystems in Interior

698 Alaska : I. Seasonal, Phenotypic, and Drought Effects on Photosynthesis and Response Patterns.” Oecologia 48 (1): 50-59. https://doi.org/10.1007/BF00346987

Snyder, W. C., Z. Wan, Y. Zhang, and Y-Z Feng. 1998. “Classification-Based Emissivity for

Starr, Gregory, and Steven F. Oberbauer. 2003. "Photosynthesis of Arctic Evergreens under Snow: Implications for Tundra Ecosystem Carbon Balance.” Ecology 84: 1415-1420.

Stoy, Paul C., Adam A. Cook, John E. Dore, Natascha Kljun, William Kleindl, E. N. Jack Brookshire, and Tobias Gerken. 2021. "Methane Efflux from an American Bison Herd."

Stoy, Paul C., Gabriel G. Katul, Mario B. S. Siqueira, Jehn-Yih Juang, Kimberly A. Novick, Heather R. McCarthy, A. Christopher Oishi, and Ram Oren. 2008. "Role of Vegetation in

714 Stoy, Paul C., Gabriel G. Katul, Mario B. S. Siqueira, Jehn-Yih Juang, Kimberly A. Novick, Determining Carbon Sequestration along Ecological Succession in the Southeastern United States." Global Change Biology 14, 1409-142. https://doi.org/10.1111/j.13652486.2008.01587.x

Joshua M. Uebelherr, and Ram Oren. 2006. “An Evaluation of Models for Partitioning Eddy Covariance-Measured Net Ecosystem Exchange into Photosynthesis and Respiration.” Agricultural and Forest Meteorology 141 (1): 2-18.

https://doi.org/10.1016/j.agrformet.2006.09.001

719 Stoy, Paul C., Erich Peitzsch, David Wood, Daniel Rottinghaus, Georg Wohlfahrt, Michael 
Goulden, and Helen Ward. 2018. "On the Exchange of Sensible and Latent Heat between https://doi.org/10.1016/j.agrformet.2018.01.028

Stoy, Paul (2021), AmeriFlux BASE US-BMM Bangtail Mountain Meadow, Ver. 2-5, AmeriFlux AMP, (Dataset). https://doi.org/10.17190/AMF/1660338

St. Peter, Joseph, John Hogland, Mark Hebblewhite, Mark A. Hurley, Nicole Hupp, and Kelly Proffitt. 2018. "Linking Phenological Indices from Digital Cameras in Idaho and Montana to MODIS NDVI.” Remote Sensing 10 (10): 1612. https://doi.org/10.3390/rs10101612

Street, Lorna E., Paul C. Stoy, Martin Sommerkorn, Benjamin J. Fletcher, Victoria L. Sloan, Timothy C. Hill, and Mathew Williams. 2012. "Seasonal Bryophyte Productivity in the Sub-Arctic: A Comparison with Vascular Plants.” Functional Ecology 26(2): 365-378.

Tenhunen, J., R. Geyer, S. Adiku, U. Tappeiner, M. Bahn, N. Q. Dinh, O. Kolcun, et al. 2009. "Influences of changing land use and $\mathrm{CO}_{2}$ concentration on ecosystem and landscape level carbon and water balances in mountainous terrain of the Stubai Valley, Austria.” Global and Planetary Change 67: 29-43. https://doi.org/10.1016/j.gloplacha.2008.12.010 https://doi.org/10.2307/1550031

742 Tieszen, L. L., and Donna C. Sigurdson. 1973. "Effect of Temperature on Carboxylase Activity 
and Stability in Some Calvin Cycle Grasses from the Arctic.” Arctic and Alpine Research

745 Van Gaalen, K. Eric, Lawrence B. Flanagan, and Derek R. Peddle. 2007. "Photosynthesis,

746 Chlorophyll Fluorescence and Spectral Reflectance in Sphagnum Moss at Varying Water

747 Contents." Oecologia 153 (1): 19-28. https://doi.org/10.1007/s00442-007-0718-y

748 Vickers, Dean, and L. Mahrt. 1997. “Quality Control and Flux Sampling Problems for Tower

749 and Aircraft Data.” Journal of Atmospheric and Oceanic Technology 14 (3): 512-26.

750 https://doi.org/10.1175/1520-0426(1997)014<0512:QCAFSP $>2.0 . C O ; 2$

751 Viljanen, Niko, Eija Honkavaara, Roope Näsi, Teemu Hakala, Oiva Niemeläinen, and Jere

752 Kaivosoja. 2018. “A Novel Machine Learning Method for Estimating Biomass of Grass

753 Swards Using a Photogrammetric Canopy Height Model, Images and Vegetation Indices

754 Captured by a Drone.” Agriculture 8(5), 70. https://doi.org/10.3390/agriculture8050070.

755 Vitasse, Yann, Martine Rebetez, Gianluca Filippa, Edoardo Cremonese, Geoffrey Klein, and

756 Christian Rixen. 2017. “'Hearing’ Alpine Plants Growing after Snowmelt: Ultrasonic Snow

757 Sensors Provide Long-Term Series of Alpine Plant Phenology.” International Journal of

758 Biometeorology 61(2): 349-361. https://doi.org/10.1007/s00484-016-1216-X

759 Weaver, T.1977. Root distribution and soil water regimes in nine habitat types of the northern

760 Rocky Mountains, p. 239- 244. In J. Marshall 1977. The Belowground ecosystem. Range

761 Sci. Series 26, Colorado State University, Fort Collins. 351 pp.

762 Weaver, T., and D. Collins. 1977. "Possible Effects of Weather Modification (increased

763 Snowpack) on Festuca idahoensis Meadows.” Rangeland Ecology \& Management/Journal

$764 \quad$ of Range Management Archives 30 (6): 451-56.

765 Wohlfahrt, Georg, Margaret Anderson-Dunn, Michael Bahn, Manuela Balzarolo, Frank 
Berninger, Claire Campbell, Arnaud Carrara, et al. 2008. "Biotic, Abiotic, and Management

Wohlfahrt, Georg, Albin Hammerle, Alois Haslwanter, Michael Bahn, Ulrike Tappeiner, and

Wohlfahrt, G., S. Pilloni, L. Hörtnagl, and A. Hammerle. 2010. "Estimating Carbon Dioxide Fluxes from Temperate Mountain Grasslands Using Broad-Band Vegetation Indices.”

Wutzler, Thomas, Antje Lucas-Moffat, Mirco Migliavacca, Jürgen Knauer, Kerstin Sickel, 


\section{Tables}

790 Table 1: List of abbreviations with units.

\begin{tabular}{|c|c|c|}
\hline Abbreviation & Definition & Units or value \\
\hline ALB & Shortwave albedo & unitless \\
\hline $\mathrm{DN}$ & Digital number & unitless \\
\hline $\mathrm{E}_{0}$ & Related to activation energy & $\mathrm{K}^{-1}$ \\
\hline $\mathrm{F}_{\mathrm{c}}$ & Eddy flux of carbon dioxide & $\mu \mathrm{mol} \mathrm{m} \mathrm{m}^{-2} \mathrm{~s}^{-1}$ \\
\hline $\mathrm{G}$ & Ground heat flux & $\mathrm{W} \mathrm{m}^{-2}$ \\
\hline $\mathrm{GCC}$ & Green chromatic coordinate & unitless \\
\hline GPP & Gross primary productivity & $\mu \mathrm{mol} \mathrm{m}{ }^{-2} \mathrm{~s}^{-1}$ \\
\hline $\mathrm{h}$ & Height & $\mathrm{m}$ \\
\hline $\mathrm{H}$ & Sensible heat flux & $\mathrm{W} \mathrm{m}^{-2}$ \\
\hline $\mathrm{k}$ & $\begin{array}{l}\text { Parameter describing sensitivity of } \beta \text { to } \\
\text { VPD }\end{array}$ & $\mathrm{hPa}^{-1}$ \\
\hline $\mathrm{LE}$ & Latent heat flux & $\mathrm{W} \mathrm{m} \mathrm{m}^{-2}$ \\
\hline NDVI & Normalized difference vegetation index & unitless \\
\hline NDVI & NDVI from MODIS & unitless \\
\hline PPFD & Photosynthetic photon flux density & $\mu \mathrm{mol} \mathrm{m} \mathrm{s}^{-2}$ \\
\hline PRI & Photochemical reflectance index & unitless \\
\hline $\mathrm{RCC}$ & Red chromatic coordinate & unitless \\
\hline $\mathrm{R}_{\mathrm{g}}$ & Global shortwave radiation & $\mathrm{W} \mathrm{m}^{-2}$ \\
\hline RGB & Red, green, blue & See DN \\
\hline ROI & Region of interest & $\mathrm{m}^{2}$ \\
\hline SWC & Soil water content & $\%$ \\
\hline $\mathrm{T}_{0}$ & Respiration model constant & $-46.02^{\circ} \mathrm{C}$ \\
\hline TA & Air temperature & ${ }^{\circ} \mathrm{C}$ \\
\hline
\end{tabular}




\begin{tabular}{|c|c|c|}
\hline $\mathrm{T}_{\mathrm{ref}}$ & Reference temperature & $15^{\circ} \mathrm{C}$ \\
\hline Tsoil & Soil temperature & ${ }^{\circ} \mathrm{C}$ \\
\hline Tsurf & Radiometric surface temperature & ${ }^{\circ} \mathrm{C}$ \\
\hline VPD & Vapor pressure deficit & $\mathrm{hPa}$ \\
\hline $\mathrm{VPD}_{0}$ & VPD threshold for $\beta$ limitation & $10 \mathrm{hPa}$ \\
\hline$\alpha$ & Initial slope of the light-response curve & $\mu \mathrm{mol} \mathrm{CO} \mathrm{J}^{-1}$ \\
\hline$\beta$ & Light response curve at saturation & $\mu \mathrm{mol} \mathrm{m}{ }^{-2} \mathrm{~s}^{-1}$ \\
\hline$\beta_{0}$ & Maximum $\beta$ at non-limiting VPD & $\mu \mathrm{mol} \mathrm{m} \mathrm{m}^{-2} \mathrm{~s}^{-1}$ \\
\hline$\gamma$ & Fitted parameter equivalent to $\mathrm{RE}$ & $\mu \mathrm{mol} \mathrm{m} \mathrm{m}^{-2} \mathrm{~s}^{-1}$ \\
\hline$\rho_{\text {NIR }}$ & Near-infrared reflectance & unitless \\
\hline$\rho_{\text {Red }}$ & Red reflectance & unitless \\
\hline
\end{tabular}


792 Table 2: The dates of the before-snow period, snow presence (S) and inter-snow periods (IS),

793 numbered sequentially, at the Bangtail Mountain Meadow (US-BMM) eddy covariance research

794 site in Montana, USA during 2016. Light response curves were not calculated for snow periods

795 despite non-zero GPP (e.g., Figure 5) due to the frequent patchy snow conditions (e.g. Figure 1).

\begin{tabular}{|l|l|l|}
\hline Event & Dates & $\begin{array}{l}\beta\left(\mu \mathrm{mol} \mathrm{CO} \mathrm{m}^{-2} \mathrm{~s}^{-}\right. \\
\left.{ }^{1}\right)\end{array}$ \\
\hline $\begin{array}{l}\text { Before } \\
\text { Snow }\end{array}$ & $\begin{array}{l}\text { Oct. } 1 \\
\text { Oct. } 4\end{array}$ & $6.23 \pm 0.84^{\mathrm{a}}$ \\
\hline S1 & $\begin{array}{l}\text { Oct. } 5 \\
\text { Oct. } 8\end{array}$ & - \\
\hline IS1 & $\begin{array}{l}\text { Oct. } 9 \\
\text { Oct. } 11\end{array}$ & $7.07 \pm 0.58^{\mathrm{a}}$ \\
\hline S2 & $\begin{array}{l}\text { Oct. } 12 \\
\text { Oct. } 14\end{array}$ & - \\
\hline IS2 & $\begin{array}{l}\text { Oct. } 15 \\
\text { Oct. } 17\end{array}$ & $6.63 \pm 0.38^{\mathrm{a}}$ \\
\hline S3 & $\begin{array}{l}\text { Oct. } 18 \\
\text { Oct. } 21\end{array}$ \\
\hline IS3 & $\begin{array}{l}\text { Oct. } 22 \\
\text { Oct. } 28\end{array}$ & $4.62 \pm 0.19^{\mathrm{b}}$ \\
\hline S4 & $\begin{array}{l}\text { Oct. } 29 \\
\text { Oct. } 30\end{array}$ & - \\
\hline Oct. 31 & $3.44 \pm 0.15^{\mathrm{c}}$ \\
$12^{*}$ & \\
\hline
\end{tabular}

$796 *$ Measurements became unavailable for the rest of the year after Nov. 12, 2016. 
798 Table 3: The same as Table 2 but for 2017. A light response curve was not calculated for the single

799 day of available data during IS5, and the data were not significantly related to the light response

800 curve during IS4.

\begin{tabular}{|c|c|c|}
\hline Event & Dates & $\beta\left(\mu \mathrm{mol} \mathrm{CO} \mathrm{CO}^{-2} \mathrm{~s}^{-1}\right)$ \\
\hline $\begin{array}{l}\text { Before } \\
\text { Snow }\end{array}$ & $\begin{array}{l}\text { Sept. } 10 * \\
\text { Sept. } 14\end{array}$ & $2.47 \pm 0.11^{\mathrm{a}}$ \\
\hline S1 & $\begin{array}{l}\text { Sept. } 15 \\
\text { Sept. } 28\end{array}$ & - \\
\hline IS1 & $\begin{array}{l}\text { Sept. } 29 \\
\text { Oct. } 1\end{array}$ & $1.64 \pm 0.61^{\mathrm{ab}}$ \\
\hline $\mathrm{S} 2$ & $\begin{array}{l}\text { Oct. } 2 \\
\text { Oct. } 5\end{array}$ & - \\
\hline IS2 & $\begin{array}{l}\text { Oct. } 6 \\
\text { Oct. } 11\end{array}$ & $1.73 \pm 0.20^{\mathrm{ab}}$ \\
\hline S3 & $\begin{array}{l}\text { Oct. } 12 \\
\text { Oct. } 15\end{array}$ & - \\
\hline IS3 & $\begin{array}{l}\text { Oct. } 16 \\
\text { Oct. } 19\end{array}$ & $1.50 \pm 0.15^{\mathrm{b}}$ \\
\hline S4 & $\begin{array}{l}\text { Oct. } 20 \\
\text { Oct. } 21\end{array}$ & - \\
\hline IS4 & $\begin{array}{l}\text { Oct. } 22 \\
\text { Oct. } 25\end{array}$ & - \\
\hline S5 & $\begin{array}{l}\text { Oct. } 26 \\
\text { Oct. } 27\end{array}$ & - \\
\hline IS5 & Oct. 28 & - \\
\hline S6 & $\begin{array}{l}\text { Oct. } 29 \\
\text { Dec. } 18 *\end{array}$ & - \\
\hline
\end{tabular}

801 + Measurements became available on July 12, 2017, but for consistency with the 2016 study period 802 we fit light response curves using data collected for the four days preceding the first snow event 803 beginning on Sept. 10, 2017. * Measurements became unavailable for the rest of the year after 804 Dec. 18, 2017. 


\section{Figure Legends}

806 Figure 1: Three representative phenocam images taken near noon local standard time on September

80713 (A), September 19 (B), and September 30 (C), 2017. Areas outside the grass region of interest

808 (ROI) are darkened with a translucent mask.

809

810 Figure 2: Micrometeorological conditions during the 2016 study period. Periods identified as

811 having snow (Table 2) are denoted by in blue boxes. Units are $\mathrm{W} \mathrm{m} \mathrm{m}^{-2}$ for soil heat flux $(\mathrm{G})$ with

812 the convention that positive values indicate heat flux into the soil, ${ }^{\circ} \mathrm{C}$ for air temperature (TA),

813 radiometric surface temperature (Tsurf), and soil temperature (Tsoil), and \% for volumetric soil

814 water content (SWC).

815

816 Figure 3: The median normalized difference vegetation index (NDVI), photochemical reflectance

817 index (PRI), and shortwave albedo (ALB) for 11:00 - 13:00 local time during October and early

818 November 2016. Grass or snow height (h, m) was calculated as the median half-hourly sonic

819 distance measurement for each day. Periods identified as having snow (Table 2) are indicated in

820 blue boxes.

822 Figure 4: The net ecosystem exchange (NEE), gross primary productivity (GPP), ecosystem 823 respiration (RE), latent heat flux (LE), and sensible heat flux (H) during October and November

8242016 at the Bangtail Mountain Meadow, Montana, USA study site. Periods identified as having 825 snow (Table 2) are indicated in blue boxes. Units for NEE, GPP, and RE are $\left(\mu \mathrm{mol} \mathrm{CO} \mathrm{Cm}^{-2} \mathrm{~s}^{-1}\right)$ 826 and units for $\mathrm{LE}$ and $\mathrm{H}$ are $\mathrm{W} \mathrm{m}^{-2}$. 
828 Figure 5: The relationship between GPP and PPFD with fitted light response curves (equation 2)

829 for before snow and inter-snow (IS) periods (Table 1) at the Bangtail Mountain Meadow study site

830 during 2016.

831

832 Figure 6: The same as Figure 2 but for 2017. Periods identified as having snow (Table 3) are 833 indicated in blue boxes.

835 Figure 7: The same as Figure 3 but for 2017. Periods identified as having snow (Table 3) are 836 indicated in blue boxes.

838 Figure 8: The smoothed daily 90th percentile green chromatic coordinate (GCC) and red chromatic 839 coordinate (RCC) from phenocam observations at the Bangtail Mountain (MT, USA) study site 840 during 2017 for periods when the phenocam was active. Periods of snow identified using visual 841 analyses of phenocam images are indicated in blue boxes (Table 3).

843 Figure 9: The same as Figure 4 but for late August through mid-November 2017. Periods identified 844 as having snow (Table 3) are indicated in blue boxes.

846 Figure 10: The same as Figure 5 but for 2017 with inter-snow periods (IS) as described in Table 8472.

849 Figure 11: The net ecosystem exchange of carbon dioxide (NEE) measured during 2016 and 2017 850 at the Bangtail Mountain Meadow research site. Time series are constrained by measurement 
851 availability and values represent measurements and gapfilled estimates using REddyProc (Wutzler

852 et al., 2018).

853

854 Figure 12: The relationship between GPP and PPFD for the periods July 12-31 ('late July'), August

855 1-14 ('early August'), August 15-31 ('late August'), and September 1-15 ('early September'), 8562017 with fitted light response curves following Figure 5.

857

858 Figure 13: MODIS NDVI for the Bangtail Mountain Meadow study site from the MCD43A4 v006 $859500 \mathrm{~m}$ daily product. 
bioRxiv preprint doi: https:/doi.org/10.1101/2022 01.25.477606; this version posted January 25, 2022. The copyright holder for this preprint (which was not certified by peer review) is the author/funder, who has granted bioRxiv a license to display the preprint in perpetuity. It is made available under aCC-BY 4.0 International license.

\section{Figures}
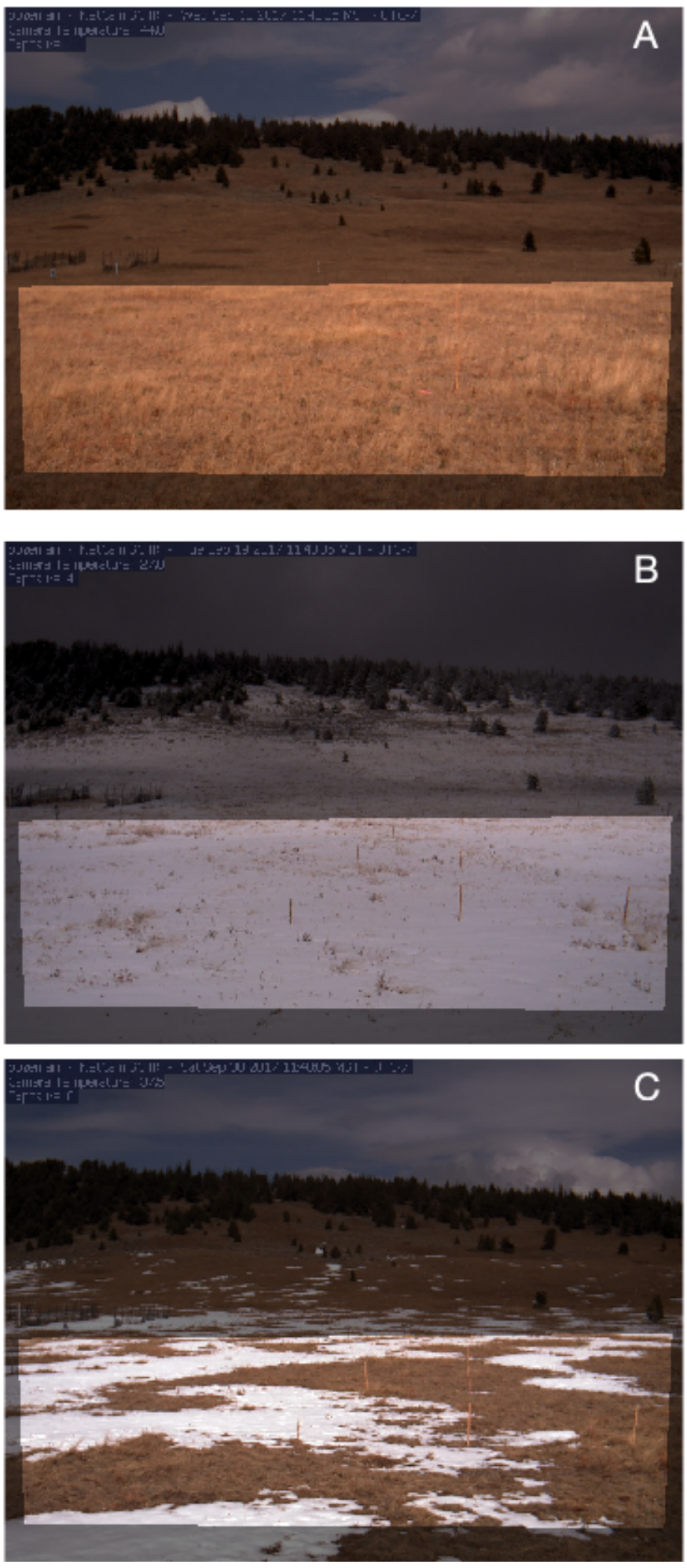

\section{$862 \quad$ Figure 1}



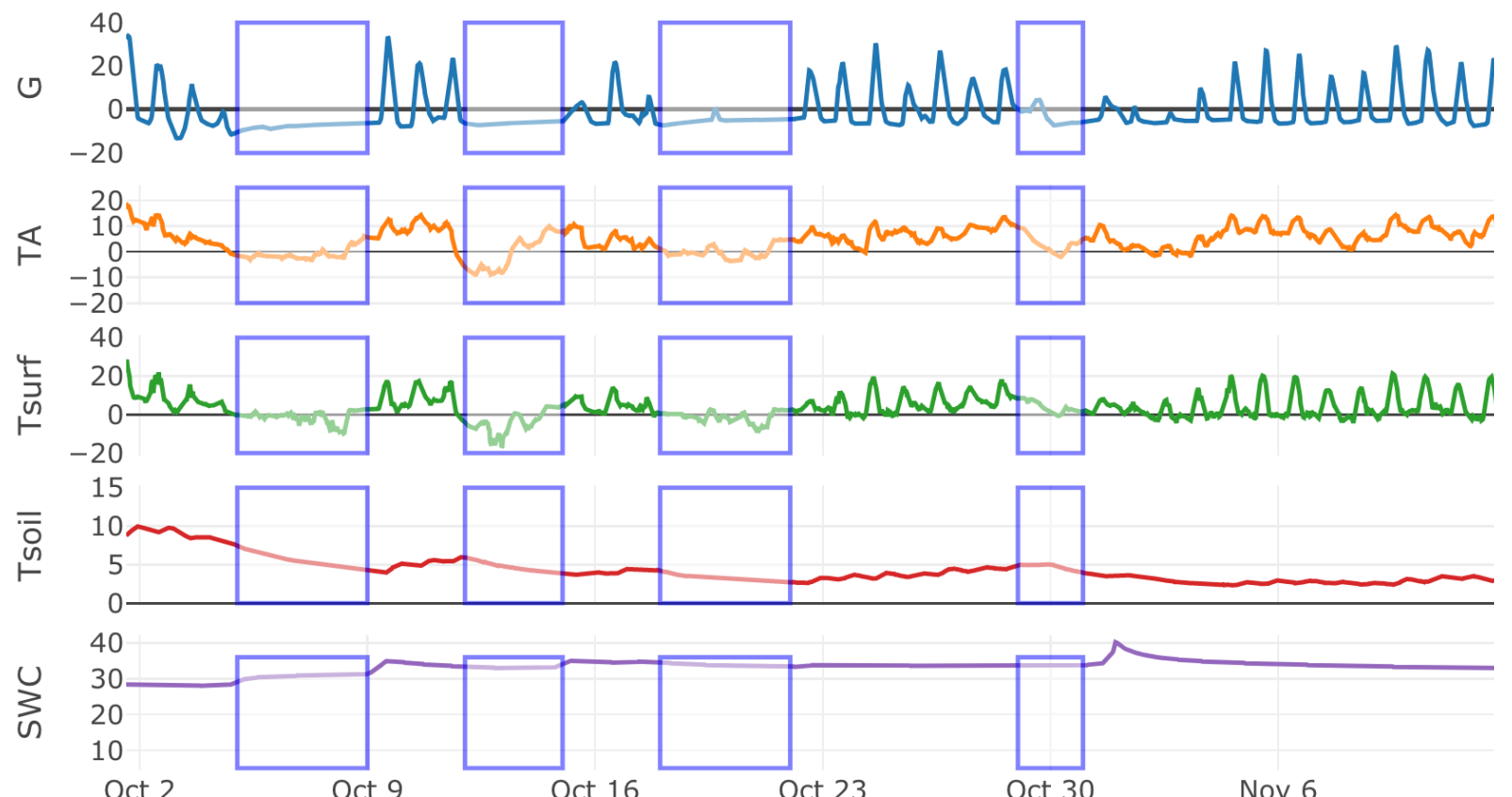

864 Figure 2
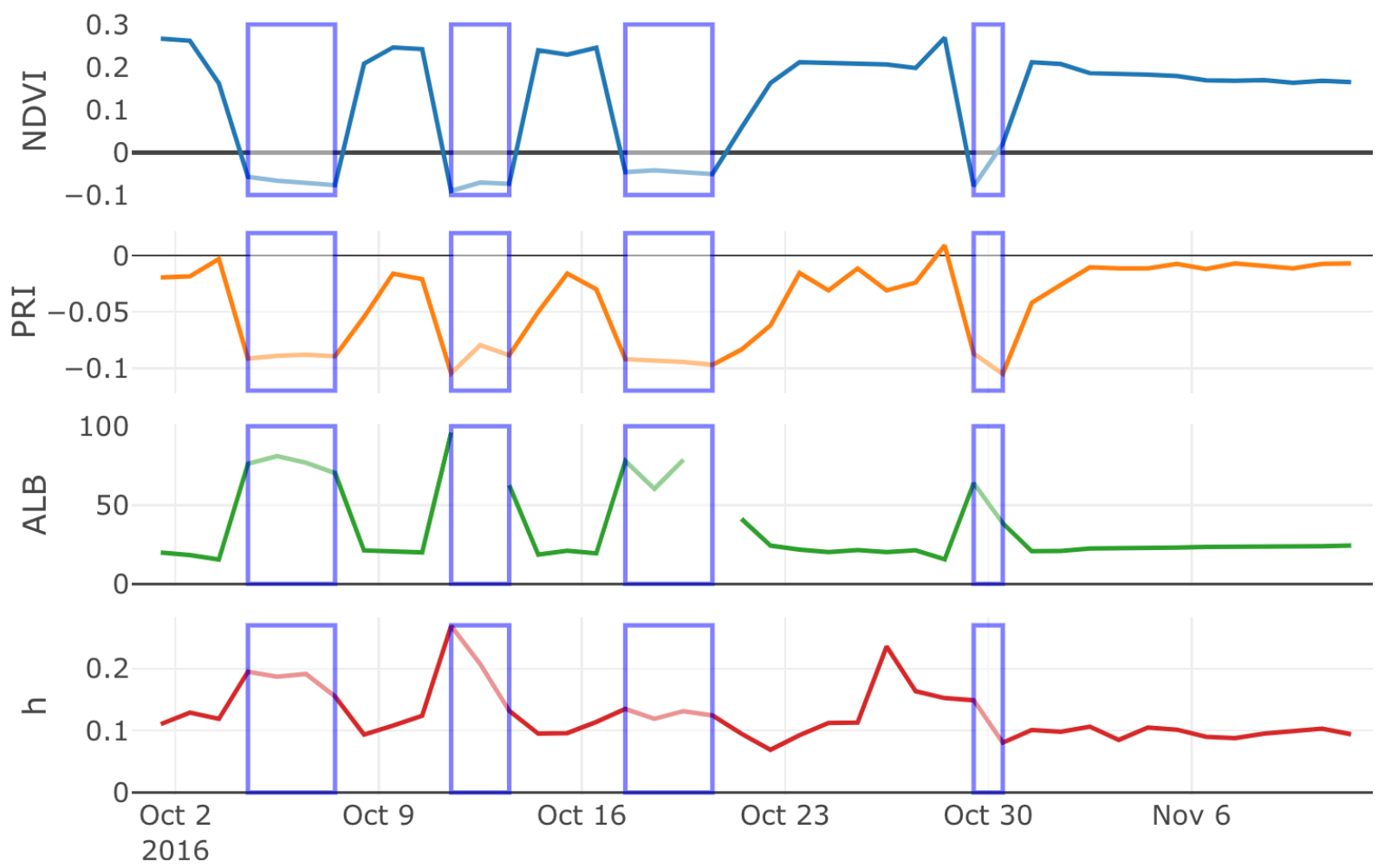

Figure 3 

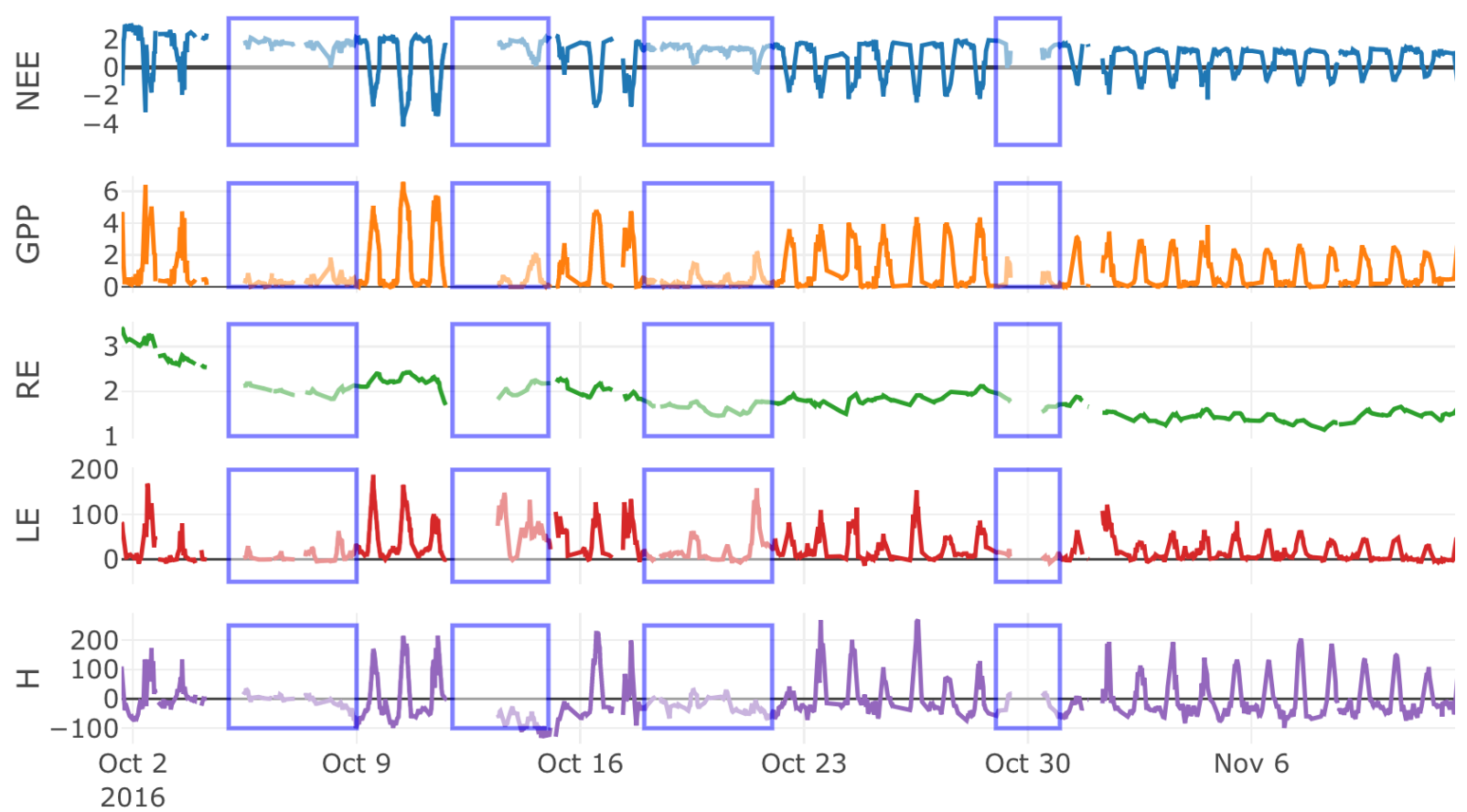

Figure 4

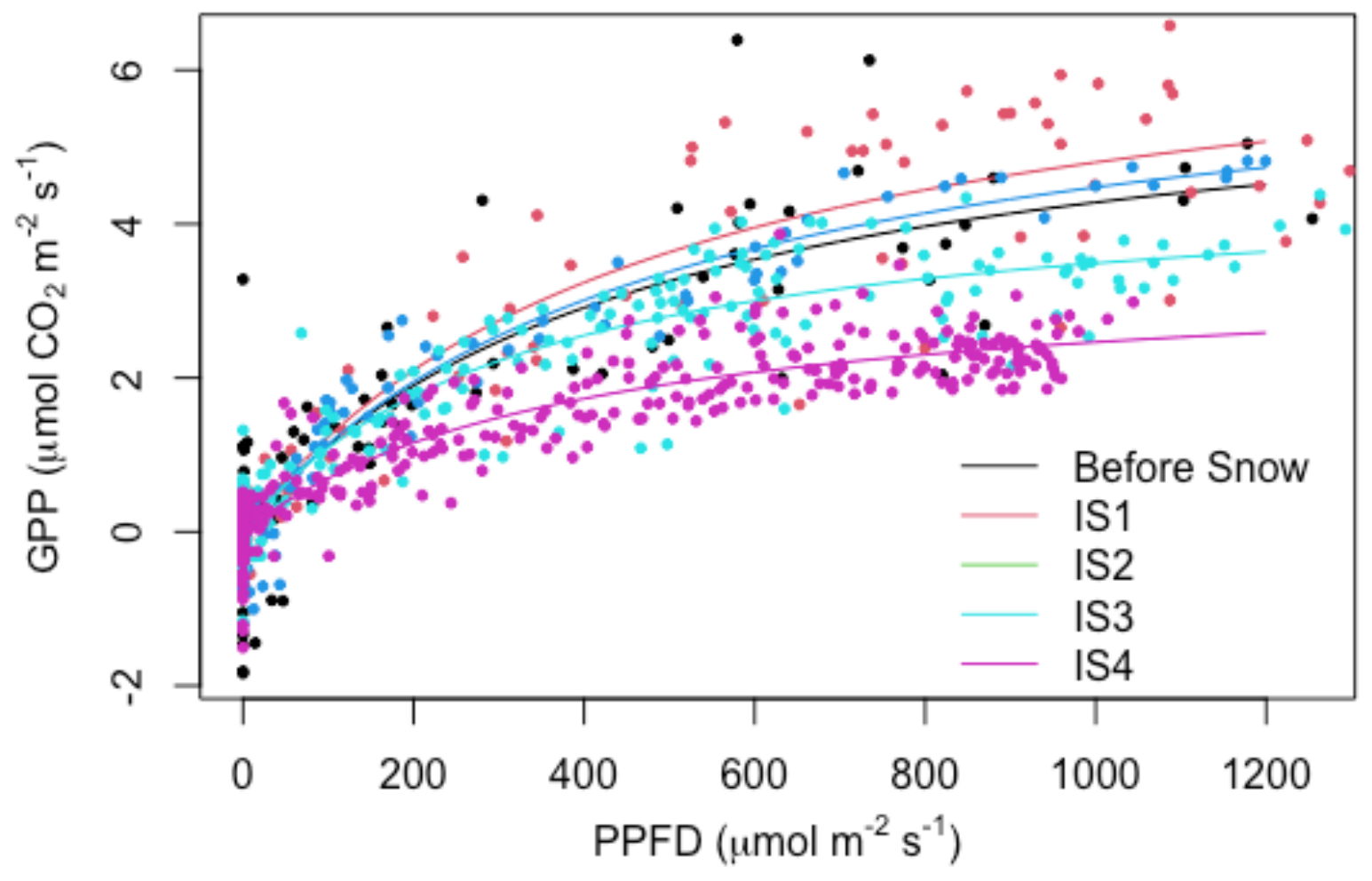

$870 \quad$ Figure 5 

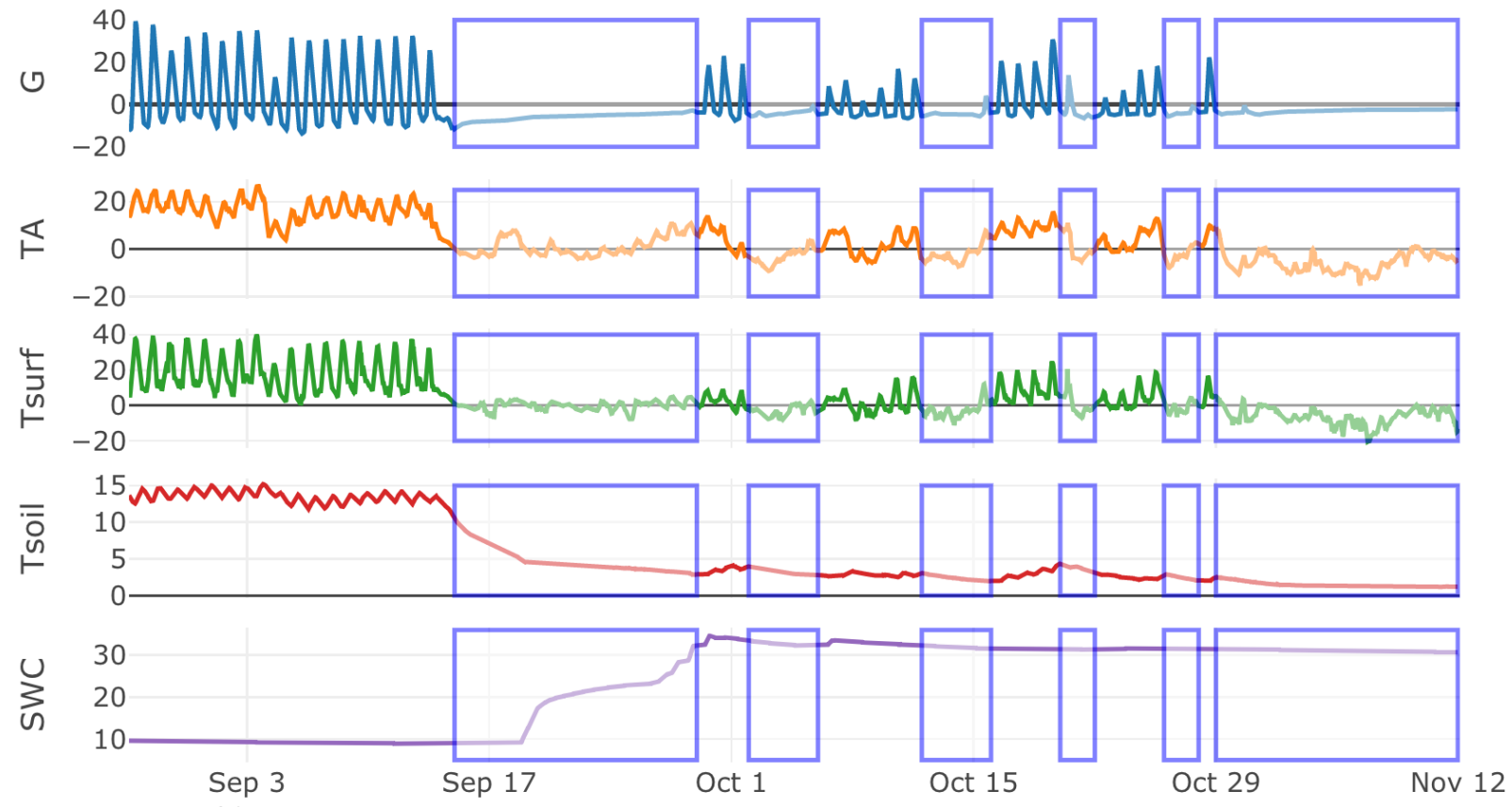

873 Figure 6
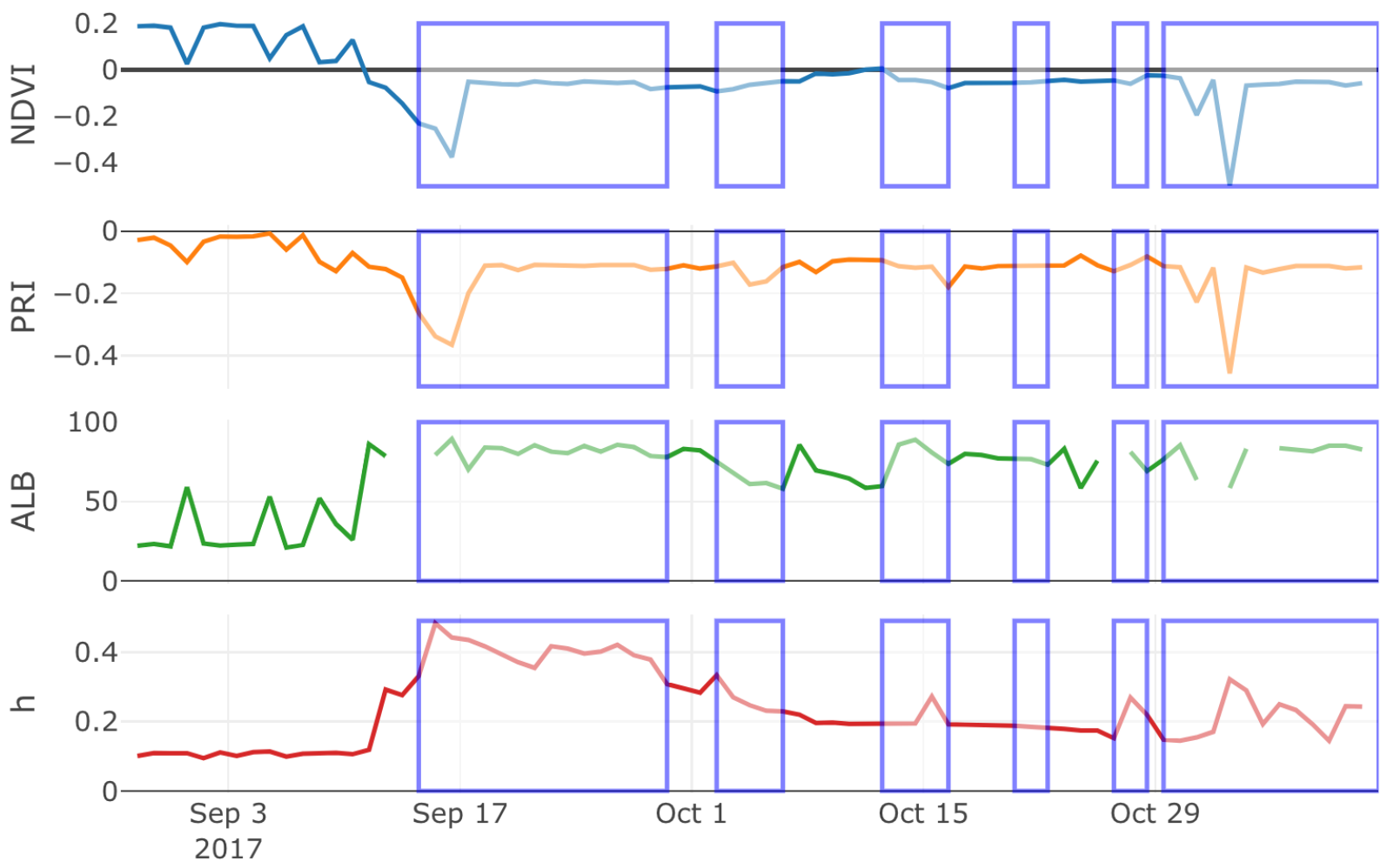

$875 \quad$ Figure 7 


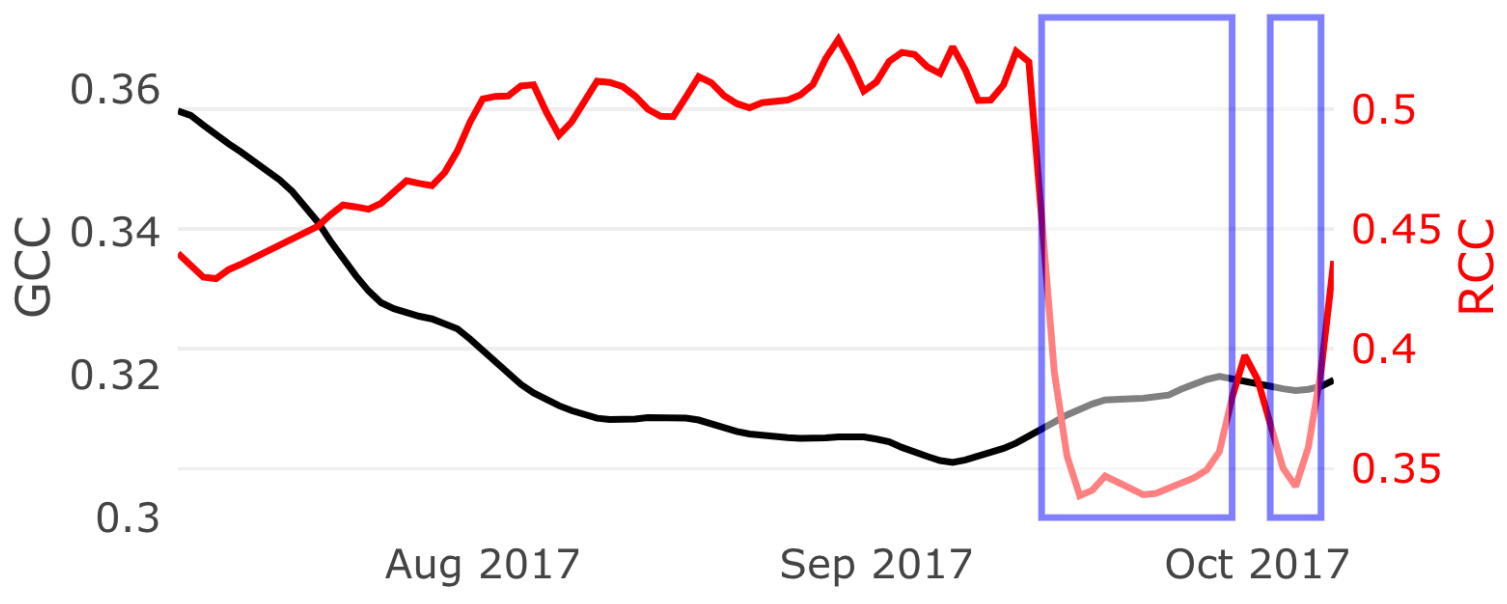

877 Figure 8

878
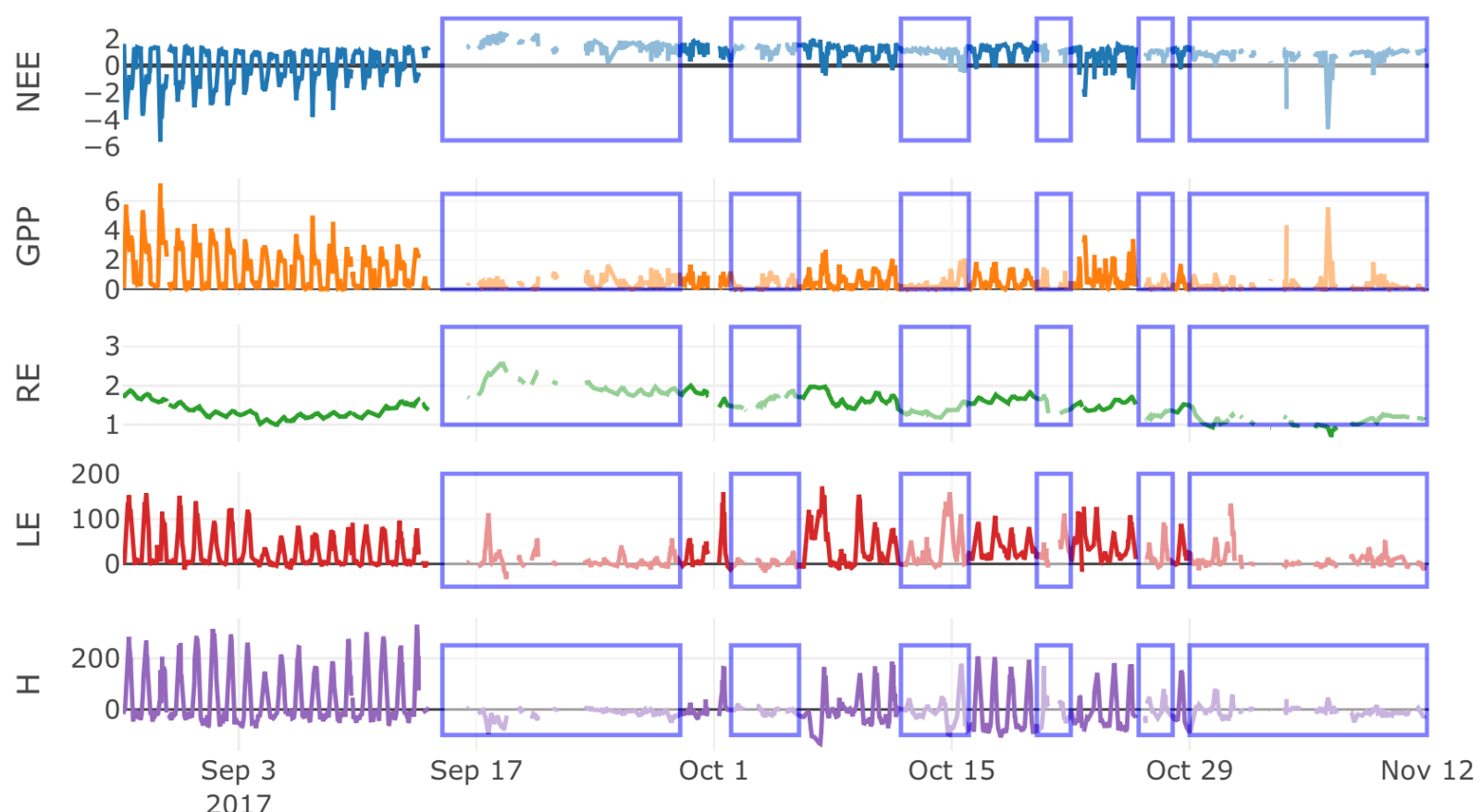

Figure 9 


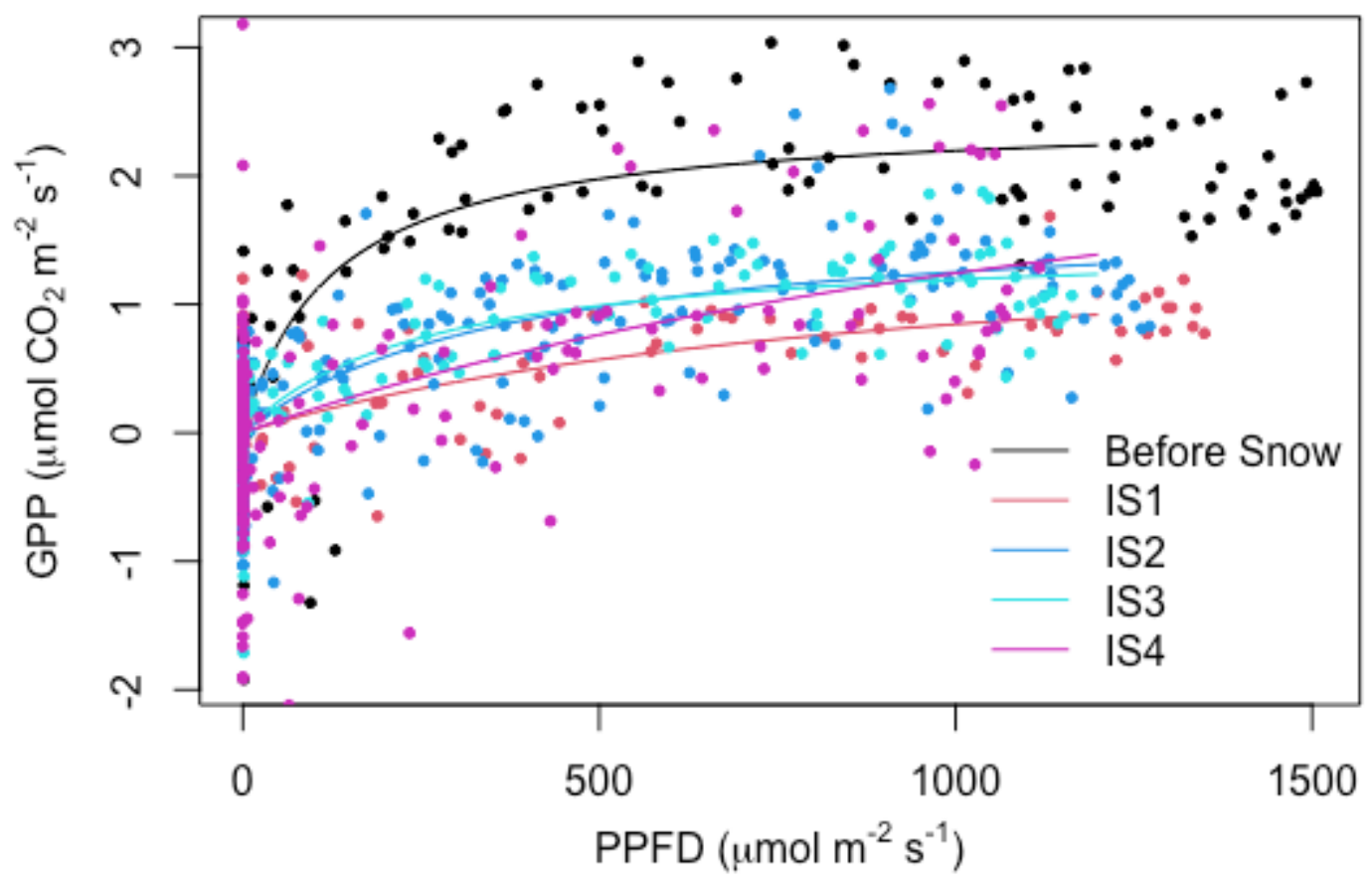

882 Figure 10

883

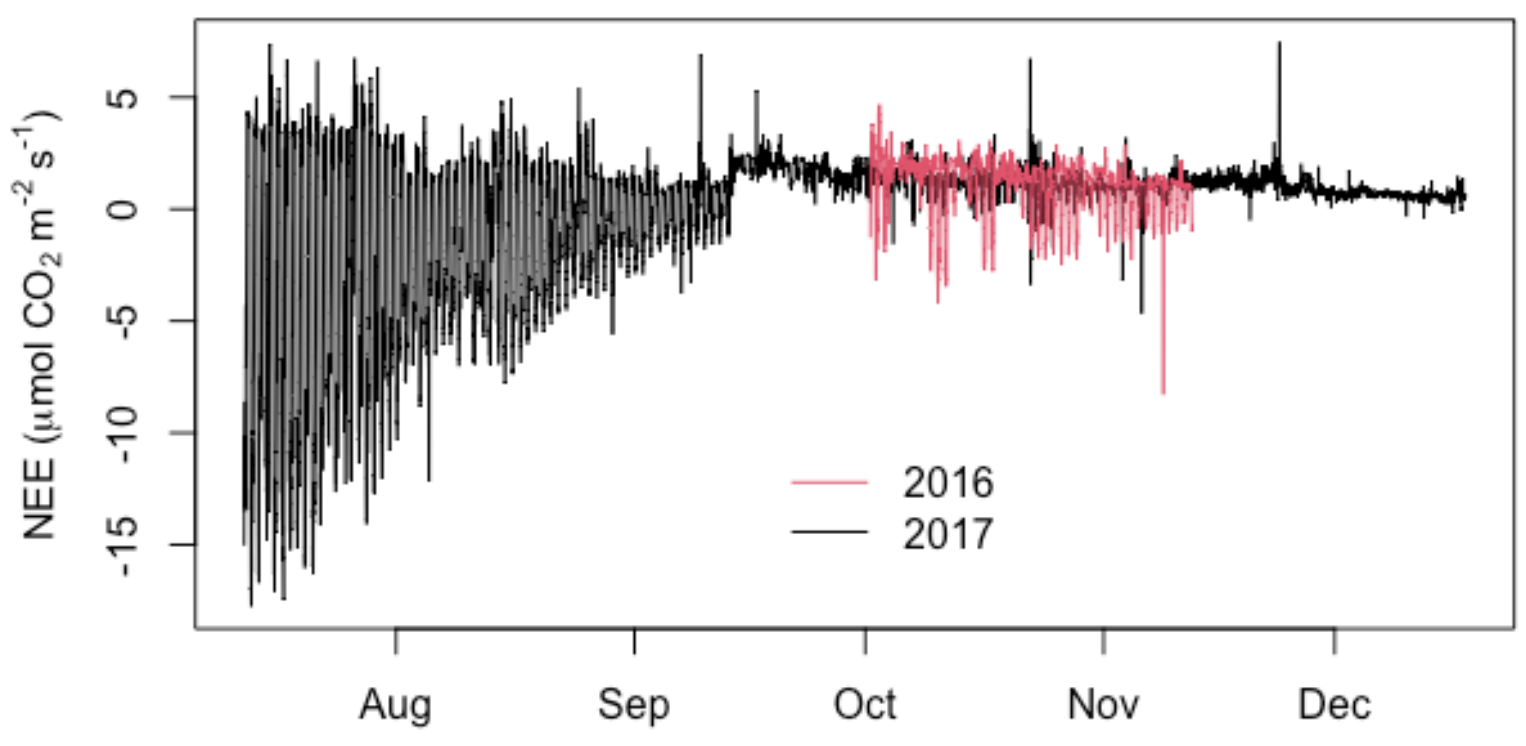

$885 \quad$ Figure 11 
bioRxiv preprint doi: https://doi.org/10.1101/2022.01.25.477606; this version posted January 25, 2022. The copyright holder for this preprint (which was not certified by peer review) is the author/funder, who has granted bioRxiv a license to display the preprint in perpetuity. It is made available under aCC-BY 4.0 International license.

887

888

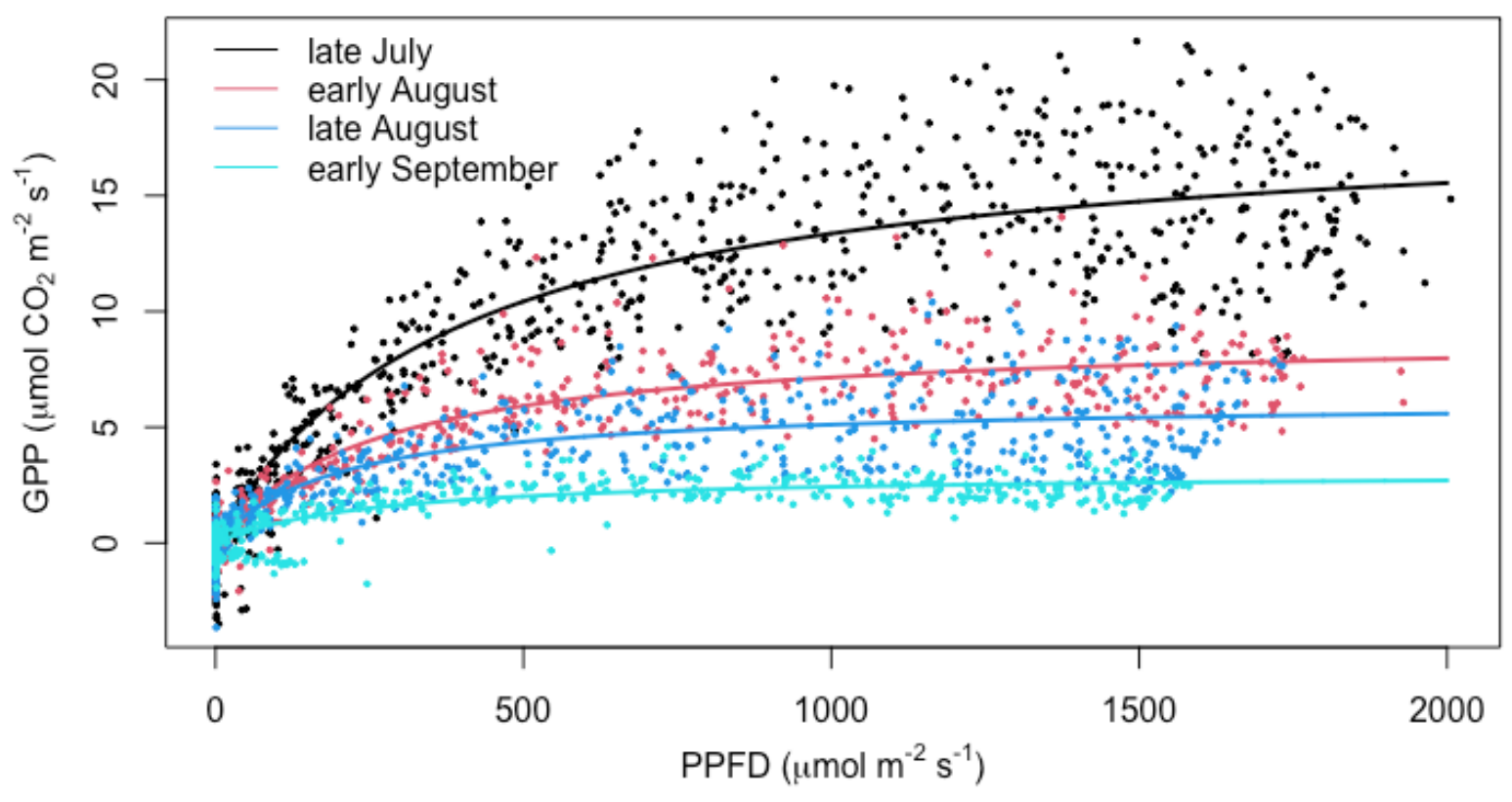

889 Figure 12

890

891

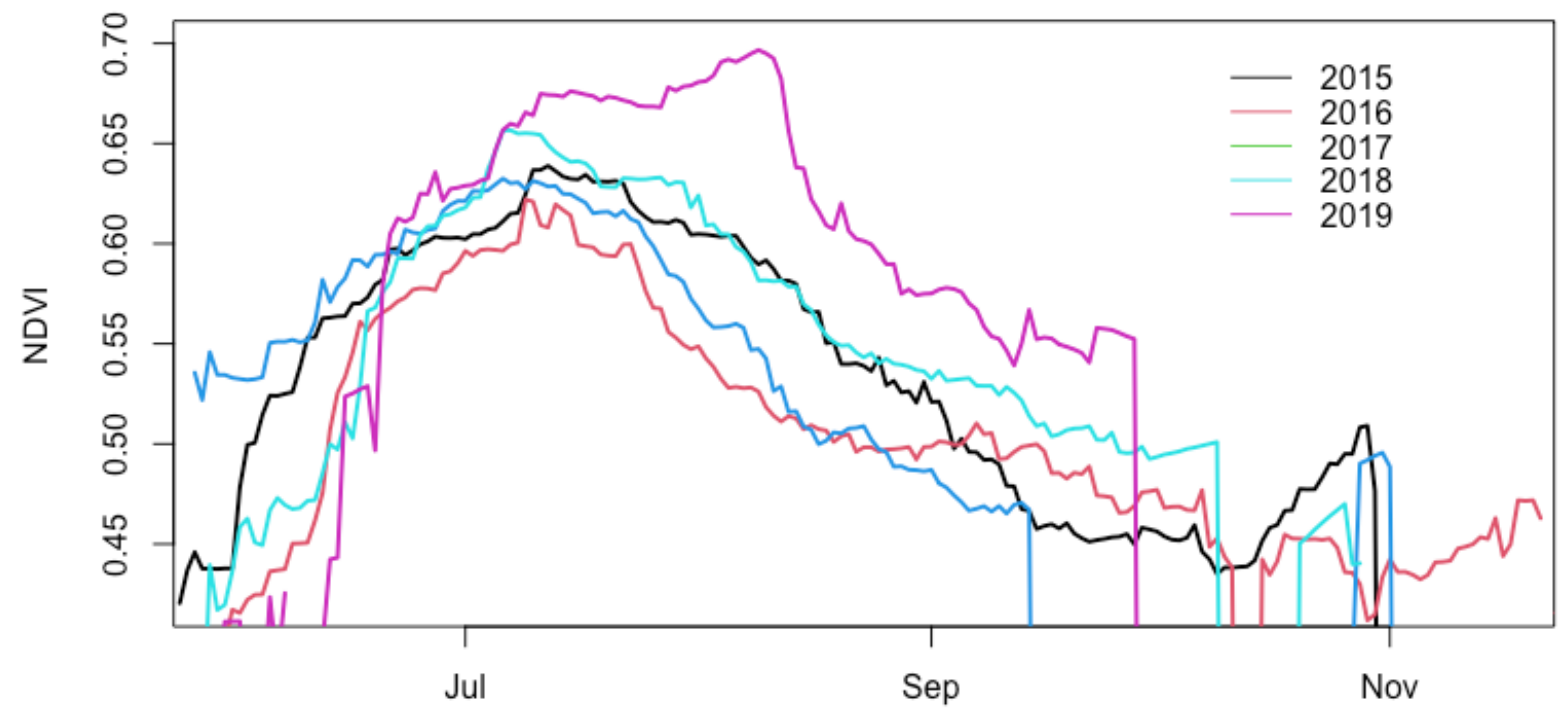

892 Figure 13 
bioRxiv preprint doi: https://doi.org/10.1101/2022 01.25.477606; this version posted January 25,2022. The copyright holder for this preprint (which was not certified by peer review) is the author/funder, who has granted bioRxiv a license to display the preprint in perpetuity. It is made available under aCC-BY 4.0 International license.

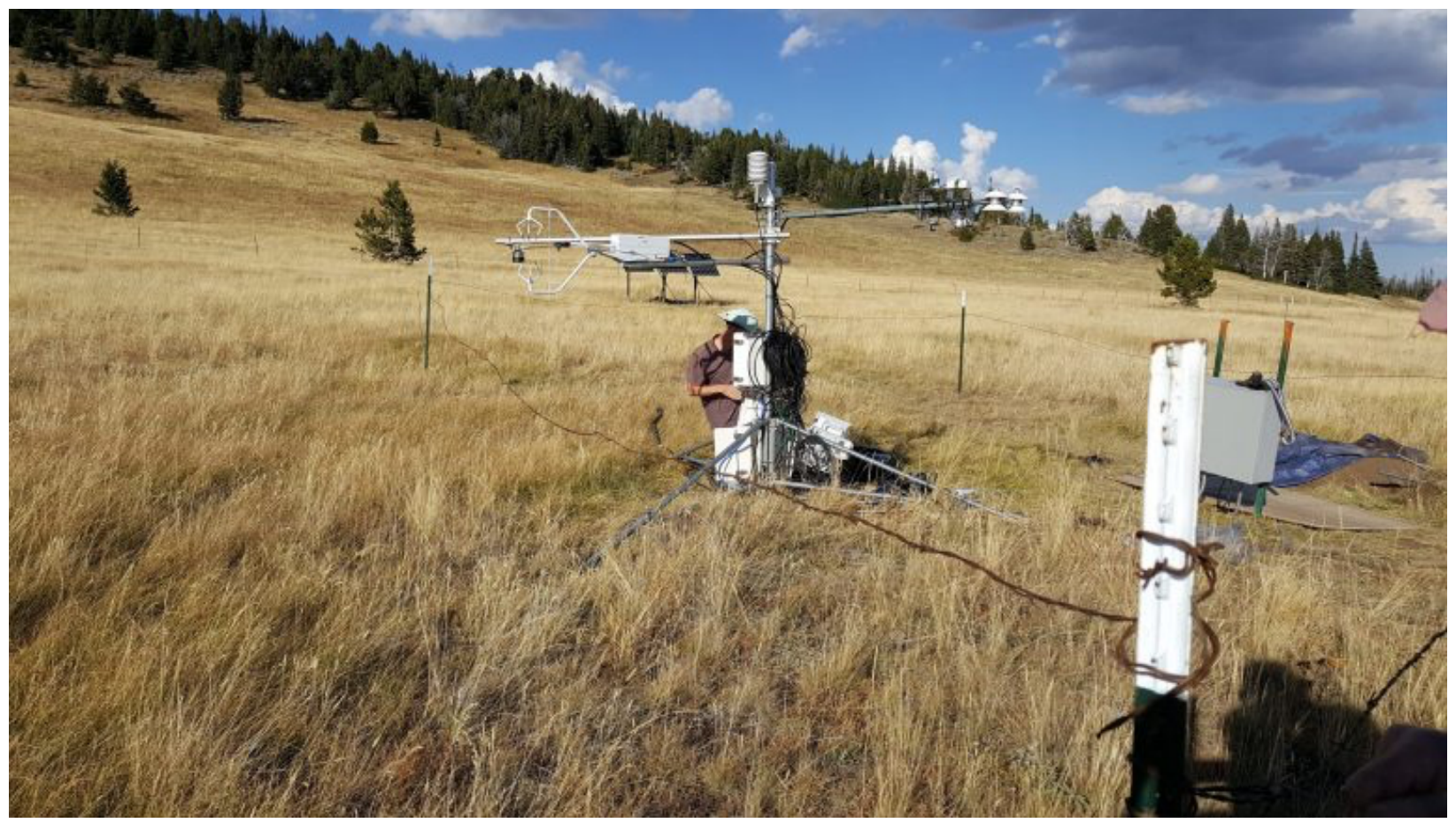

894 Figure A1: The Bangtail Mountain Meadow eddy covariance tower (US-BMM) during installation

895 on September 30, 2016. 

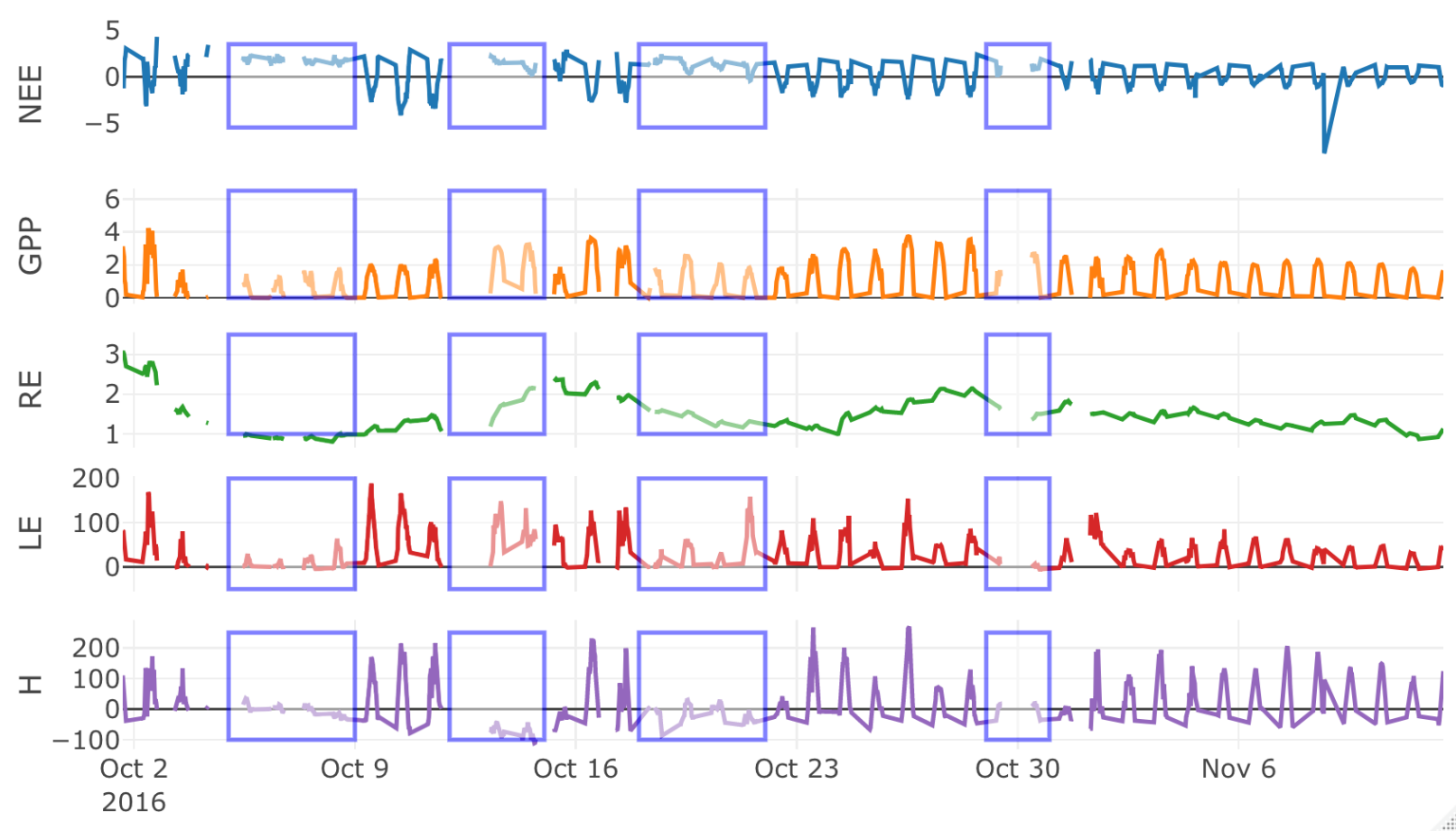

898 Figure A2: The same as Figure 4 but using the Lasslop et al. (2017) daytime flux partitioning 899 approach. 